UNIVERSIDADE DE BRASILIA - UNB

FACULDADE DE CIÊNCIAS DA SAÚDE

NÚCLEO DE ESTUDOS EM EDUCAÇÃO E PROMOÇÃO DA SAÚDE - NESPROM CENTRO DE ESTUDOS AVANÇADOS MULTIDISCIPLINAR - CEAM

CURSO DE ESPECIALIZAÇÃO EM EDUCAÇÃO E PROMOÇÃO DA SAÚDE

Ana Paula Rodrigues Lima

\title{
Dança para Síndrome de Down: uma análise dos benefícios da dança para os portadores de Síndrome de Down
}


UNIVERSIDADE DE BRASILIA - UNB

FACULDADE DE CIÊNCIAS DA SAÚDE

NÚCLEO DE ESTUDOS EM EDUCAÇÃO E PROMOÇÃO DA SAÚDE - NESPROM CENTRO DE ESTUDOS AVANÇADOS MULTIDISCIPLINAR - CEAM

CURSO DE ESPECIALIZAÇÃO EM EDUCAÇÃO E PROMOÇÃO DA SAÚDE

Ana Paula Rodrigues Lima

\title{
Dança para Síndrome de Down: uma análise dos benefícios da dança para os portadores de Síndrome de Down
}

\begin{abstract}
Trabalho de Conclusão de Curso - TCC Apresentado para a Banca Examinadora do Curso de Educação e Promoção da Saúde da Universidade de Brasília, como exigência parcial da obtenção do grau de especialista em Educação e Promoção da Saúde.
\end{abstract}

Professor Msc. Flávio Luis Leite Sousa 
Dedico este trabalho em especial a minha mãe, Eanes Botelho Fonseca, por todos os dias de amor e dedicação. $\mathrm{E}$ aos meus irmãos e sobrinhos pela compreensão durante minha formação. 


\section{AGRADECIMENTOS}

A Deus por prestar diariamente o coração que pulsa, o oxigênio que respiramos, o solo que caminhamos e milhões de itens para que existamos.

A minha familiares e amigos pela força, incentivo e pela confiança com que sempre me prestigiaram.

Aos meus colegas de curso que estiveram nessa caminhada com muita garra, vivenciando experiências e possibilitando o nosso crescimento e sempre nos motivando a não desistir.

A todos os professores pela enorme contribuição do nosso aprendizado e por mostrar a visão de um mundo melhor.

Ao meu orientador Flávio Sousa pela enorme contribuição neste trabalho. 
"Cada corpo tem o dever e o direito de escrever a sua própria história. Assim podemos cada vez mais nos respeitar, respeitar ao próximo e buscar na vida o tecer dos sentidos, em todos os sentidos”.

Lucidélia Carpanedo Fiório. 


\section{RESUMO}

A dança reduz os fatores de riscos de doenças cardiovasculares, os distúrbios do aparelho locomotor e até mesmo a depressão e ansiedade. Dentre os aspectos terapêuticos da dança estão os relatos conscientes da melhoria do humor, diminuição da depressão e do estresse, dando sustentação, força e sentido aos pronunciamentos verbais e posições no espaço que o homem executa ao se relacionar com o grupo. O objetivo deste estudo é analisar a influência benéfica da dança em indivíduos portadores de Síndrome de Down. Para isto foi realizada uma revisão bibliográfica sobre a história da dança, e a Síndrome de Down falando de sua história, causas genéticas, incidência, prevalência e suas características. Também foi desenvolvida uma pesquisa prática por meio de entrevistas com profissionais que trabalham na Associação de Pais e Amigos dos Excepcionais (APAE) de Imperatriz sobre o tema proposto. As idéias aqui apontadas mostram que a dança é uma ferramenta de inserção social, promoção da saúde e melhoria na qualidade de vida para o portador da Síndrome de Down, onde cada um responderá de maneira única aos estímulos que a dança irá lhe proporcionar. Nem sempre dançar será prazeroso, mais se pode mudar este conceito mostrando que todos são capazes de realizar gestos, movimentos e pensamentos aprendendo a atuar numa esfera cognitiva que terá motivações internas. Sendo assim, a dança é um meio de tornar indivíduos portadores de Síndrome de Down independentes na comunidade tendo nela uma interação com o mundo, seja para enfrentar barreiras, romper preconceitos, lutar pela igualdade de capacidades, se integrarem com o mundo e consigo e tentarem viver como uma pessoa não deficiente.

PALAVRAS CHAVES: Dança, Síndrome de Down, Benefícios 
SUMÁRIO

\begin{tabular}{|c|c|}
\hline & MO \\
\hline 1 & INTRODUÇÃO . \\
\hline 2 & OBJETIVOS... \\
\hline 3 & 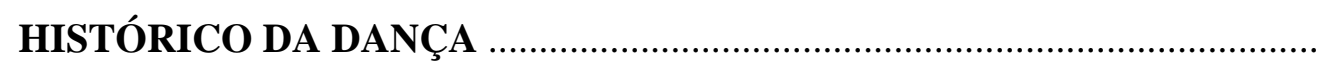 \\
\hline 3.1 & 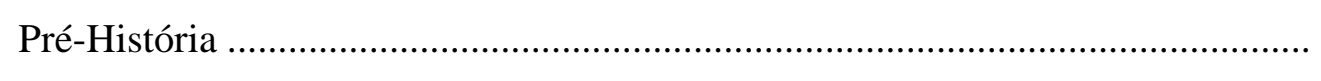 \\
\hline 3.2 & Idade Antiga ....................... \\
\hline 3.2 .1 & Dança Hebraica .... \\
\hline 3.2 .2 & 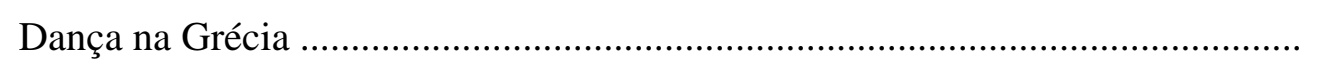 \\
\hline 3.2 .2 & Império Romano ........................ \\
\hline 3.3 & Idade Média ................................ \\
\hline 3.4 & Idade Moderna ......... \\
\hline 3.5 & Dança no Brasil ......................... \\
\hline 4 & CONCEITO DE DANÇA .. \\
\hline 5 & BENEFÍCIOS DA DANÇA. \\
\hline 6 & SÍNDROME DE DOWN ... \\
\hline 6.1 & 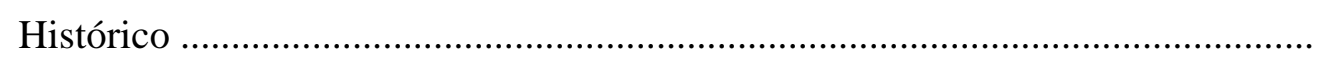 \\
\hline 6.2 & 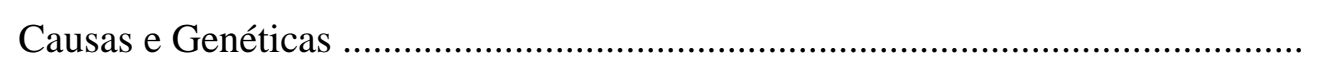 \\
\hline 6.3 & Incidência e Prevalência ........ \\
\hline 6.4 & 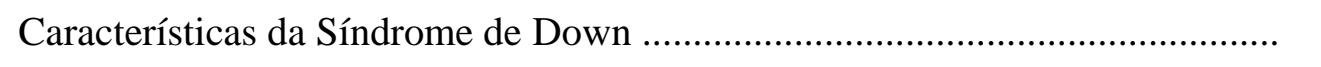 \\
\hline 7 & DANÇA E A SÍNDROME DE DOWN .................... \\
\hline 8 & 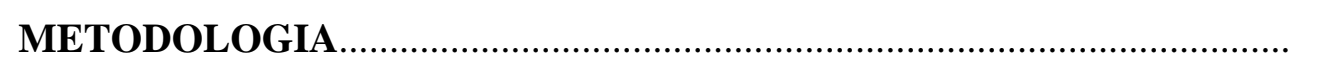 \\
\hline 9 & RESULTADOS......... \\
\hline 10 & DISCUSSÃO........................... \\
\hline 11 & CONCLUSÃO \\
\hline 12 & REFERÊNCIAS \\
\hline
\end{tabular}




\section{INTRODUÇÃO}

Pouco se tem na literatura a respeito da dança para Síndrome de Down, escrever sobre esse assunto requer uma linguagem muito ousada porque atinge as áreas de construção do indivíduo a partir do seu corpo e mente.

A dança é apenas um meio de torná-los independentes na comunidade tendo nela uma interação com o mundo, seja para enfrentar barreiras, romper preconceitos, lutar pela igualdade de capacidades, se integrar com o mundo e consigo, tentar viver como uma pessoa não deficiente.

Segundo Sérgio (2001) "não há pessoas deficientes, há pessoas diferentes. De educação especial é bem possível que todos precisemos”. E o que se pretende neste trabalho é mostrar que através da dança as pessoas diferentes podem vivenciá-la e obter uma forma de viver normal como qualquer pessoa não deficiente e mostrar para a sociedade que os portadores de Síndrome de Down são capazes de fazer coisas antes ditas impossíveis.

Esse trabalho foi desenvolvido através de um relato sobre dança, com seu histórico, conceito e benefícios. Logo após há um relato sobre a Síndrome de Down falando de sua história, causas genéticas, incidência, prevalência e suas características para então chegar ao foco principal do nosso trabalho: Dança para portadores de Síndrome de Down. Por último, a pesquisa de campo que traz a visão de alguns profissionais a respeito da Síndrome de Down.

De início sentiu-se a necessidade que o leitor tomasse conhecimento sobre a história da dança, desde os primórdios, para uma melhor compreensão de como e porque o homem dançava e suas influências sobre o mundo e conseqüentemente no Brasil. E que ao longo de toda a sua história até os dias atuais a dança serve como um meio de linguagem não verbal como forma de expressão e comunicação da vida humana.

Em relação à Síndrome de Down houve o interesse em descrever um pouco sobre sua história demonstrando suas causas e genéticas, sua incidência e prevalência para podermos classificá-las e compreender suas características e suas deficiências. Salientando-se também a importância da dança para portadores de Síndrome de Down dentro da sociedade, onde essas pessoas são pouco valorizadas. Demonstra ainda as investigações feitas nessa área no sentido de descobrir quais os benefícios que a dança irá proporcioná-los

Com essa consciência da importância da dança harmônica e estimulativa no processo 
de raciocínio, reabilitação, fortalecimento, prazer, prevenção, desejo e aumento do convívio social, surge então à necessidade de adaptar todo o meio social, esportivo e recreativo para que o portador de Síndrome de Down possa se deleitar neste convívio. Os permitindo identificar e analisar a beleza de todos os movimentos que seu corpo é capaz de presentear, com o que fala e o papel dos outros do discurso verbal e não verbal significando o corpo verbalmente.

Assim, este trabalho objetiva dentre outras coisas contrapor certas crenças de que o portador de Síndrome de Down é incapaz de dançar e de conviver em sociedade. A partir dessas descobertas algumas medidas podem ser tomadas transformando a dança em um espetáculo de divertimento a essas pessoas.

Em todo o trabalho objetiva-se por meio da dança que os indivíduos com Síndrome de Down obtenham um melhor condicionamento muscular e que estimule o desenvolvimento de suas capacidades, proporcionando-os o conhecimento do corpo, a busca de sua independência e satisfação de suas necessidades.

A partir dessas observações sente-se a necessidade de perceber o papel da dança frente ao portador de Síndrome de Down, no sentido de buscar uma melhoria de vida a esses indivíduos dando-lhes a oportunidade de "lutar pela vida, pela paixão e o desejo de ser diferente e igual ao mesmo tempo, a todo instante” (FIGUEIREDO; TAVARES; VENÂNCIO, 1999). 


\section{OBJETIVOS}

\section{Objetivo Geral}

Analisar a influência benéfica da dança em indivíduos portadores de Síndrome de Down.

\section{Objetivos Específicos}

- Conhecer o histórico da dança, seus conceitos e benefícios;

- Identificar as causas genéticas, incidência, prevalência e as características da Síndrome de Down;

- Conhecer a dança para portadores de Síndrome de Down;

- Traçar estratégias de promoção e educação em saúde, visando à melhoria da qualidade de vida do portador de Síndrome de Down. 


\section{HISTÓRICO DA DANÇA}

É difícil determinar hoje em dia quando, como e por que o homem dançou pela primeira vez. Há quem distinga nas figuras gravadas nas cavernas de Lascaux, pelo homem pré-histórico, figuras dançando. E como o homem da idade da pedra só gravava nas paredes de suas cavernas aquilo que lhe era importante, como a caça, a alimentação, a vida e a morte, é possível que essas figuras dançantes fizessem parte de rituais de cunho religioso, básicos para a sociedade de então, a cujos costumes esse tipo de manifestação já estaria incorporado (FARO, 1986, p.13).

\subsection{Pré-História}

Acredita-se que a dança é tão importante para os homens pré-históricos quanto os animais e as caçadas, pois foi nas figuras gravada nas cavernas de Lascaux ${ }^{1}$ que arqueólogos encontraram nas regiões da Europa e da África do Sul desenhos com um mesmo movimento. Nelas, a cabeça está voltada para frente, o tronco apresenta-se num falso perfil, os dois braços em semi-extensão, com o direito um pouco mais alto que o esquerdo. O corpo está inclinado em relação às pernas, que estão levemente flexionadas. A perna esquerda está à frente da direita, com o pé no chão, e o pé direito está em relevé. Contudo, Fahlbusch (1990, p.15) ressalta que “a dança é tão velha quanto à própria vida humana. Antes de usar a palavra, o homem já se servia do movimento corporal, dos gestos primitivos pressionado pelo ritmo natural de suas emoções”.

Garaudy (1980, p.19) relata que “a dança é considerada para todos os povos em todos os tempos, um meio de comunicação e expressão” e é através de gestos, símbolos e signos que se pode destacar a influência da dança e sua significância nos acontecimentos diários dos homens primitivos como: nascimento, casamento, mortes, caça, guerras, iniciação dos adolescentes, doenças, cerimônias tribais, vitórias, paz, primaveras, sementeira, colheita, festas do sol, da lua, da fertilidade (Figura 01).

\footnotetext{
1 Lascaux: É uma complexo de cavernas ao sudoeste de França. É muito famosa pela suas pinturas rupestres. Origem: Wikipédia, a enciclopédia livre
} 


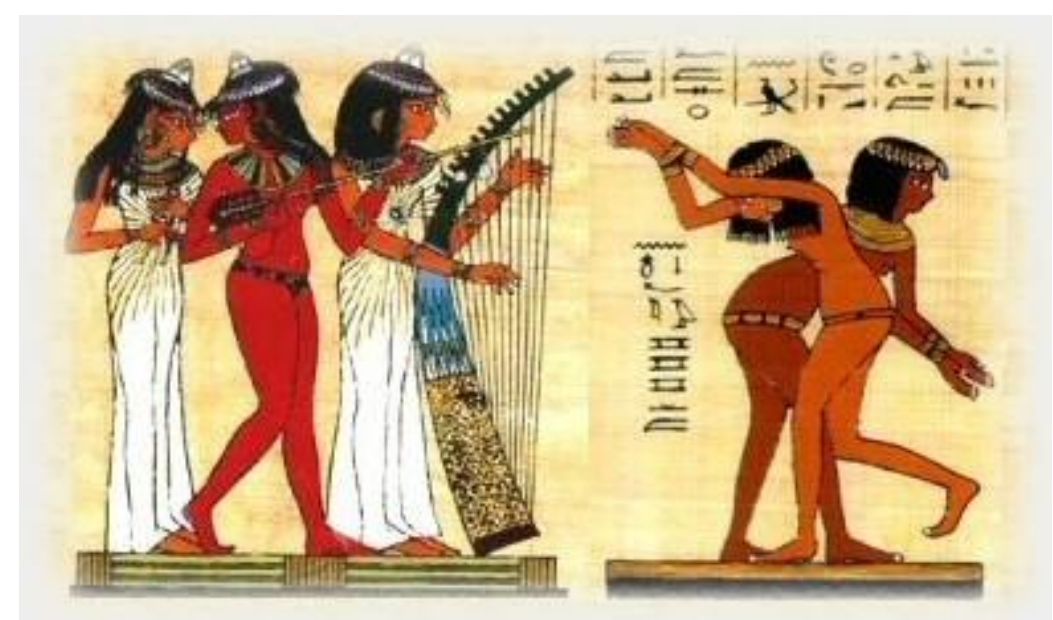

Figura 1- As mulheres dançavam geralmente reverenciando deuses.

Fonte: http://miradacriadora_pre_antig.uniblog.com.br/index.php?b=30466\&d=m $\underline{\& d} 2=1149130800$

Assim já nos primórdios a dança se revela como produto e o fator da cultura humana. A antítese entre os movimentos "amplos" e os "estreitos", marca, inclusive, o contraste da própria natureza dos sexos. O fato é bem conhecido, que o homem é mais apto para os movimentos amplos - saltos, passos grandes, etc. - enquanto a mulher, em geral, tem inclinação para os movimentos estreitos curtos, pequenos, em contato contínuo com o solo, opondo à audácia e ao dinamismo másculo, a prudência, a calma, a graça harmoniosa. Enquanto o homem salta intrepitosamente no ar, a mulher apenas se alça nas pontas dos pés (FAHLBUSCH, 1990, p. 16).

Para Fahlbusch (1990, p.16) “desde o início da vida humana, são três as formas fundamentais de dança: - em ‘solo’, em ‘pares’ e em 'grupo’”. A dança “solo” tornou-se com o tempo, o apanágio do chefe da tribo, que com sua dança mágica assegurava a marcha feliz da vida da comunidade. A dança em "pares" tinha como a união dos dançarinos para simbolizar a fertilidade, o crescimento da própria tribo. Ossona apud Bregolato (2000, p.75) diz que "a forma mais característica da dança importante em grupo era o círculo, onde com a evolução, passaram a realizar movimentos idênticos por todos”. Fahlbusch (1990, p.16) descreve que a dança "era praticada em círculo, para que as forças magnéticas das pessoas que formavam o círculo, penetrassem no dançarino, ou vice-versa”.

Para acompanhar todos os movimentos os homens primitivos Bregolato (2000, p.75) “produziam sons estalando os dedos, batendo palmas e os pés no chão. Os movimentos eram 
acompanhados por tambores, cabaças esvaziadas e cheias de pedrinhas ou sementes, ou ainda flautas de bambu".

Segundo Faro (1986, p.13) “a dança é fruto da necessidade de expressão do homem” e que lhe servia para acalmar um deus, pedir-lhes mais sucesso nas caçadas e lutas ou de demonstrar a alegria por algo de bom concedido pelo destino. Assim, Xamã acredita que a dança pode curar o indivíduo insuflando-lhe a vida maior do Todo, já o feiticeiro de Casamance, que ela pode, a um só tempo, conjurar os mortos e evocar ou reativar o poder do ancestral nos ritos funerários.

\subsection{Idade Antiga}

Durante a Idade Antiga a história da dança pode ser dividida em: Dança Hebraica, Dança na Grécia e Império Romano.

\subsubsection{Dança Hebraica}

Proibidos pela religião de representarem os seres vivos, a dança hebraica foi a única a não a se transformar em arte tornando-se mais espontânea e dançada em multidões.

A Bíblia nos revela a presença da dança no Êxodo (BÍBLIA, 2008):

- (Êxodo 15,20) “A profetisa Maria, irmã de Aarão, tomou seu tamborim na mão, e todas as mulheres seguiram-na dançando com tamborins".

-(Êxodo 32,19) “Aproximando-se do acampamento, viu o bezerro e as danças. Sua cólera se inflamou, arrojou de suas mãos as tábuas e quebrou-as ao pé da montanha”.

Já no livro de Juízes (BÍBLIA, 2008):

-(Juízes 11,34) “Ora, voltando Jefté para a sua casa em Masfa, eis que sua filha saiu-lhe ao encontro com tamborins e danças. Era a sua única filha, porque, afora ela, não tinha filho nem filha”.

-(Juízes 16,25) "E estando eles de coração alegre, exclamaram: Mandai vir Sansão para nos divertir! Tiraram-no da prisão, e Sansão teve que dançar diante deles. Tendo sido colocado entre as colunas," 
-(Juízes 16,27) “Ora, o templo estava repleto de homens e mulheres, e estavam ali todos os príncipes dos filisteus; havia cerca de três mil pessoas, homens e mulheres, que do teto olhavam o prisioneiro dançar”.

-(Juízes 21,21) "Quando virdes as filhas de Silo saírem para dançar em coro, saí de repente das vinhas e cada um tome uma para mulher entre as filhas de Silo; depois disso voltai para a terra de Benjamim”.

-(Juízes 21,23) "Assim fizeram os benjaminitas: tomaram entre as dançarinas mulheres segundo o seu número; tomaram-nas e voltaram para a sua casa. Depois construíram cidades e habitaram nelas”.

Em Salmos, no Antigo e Novo Testamento pode-se encontrar (BÍBLIA, 2008):

-(I Samuel 18,6) "Voltando o exército, depois de Davi ter matado o filisteu, de todas as cidades de Israel saíam as mulheres ao encontro do rei Saul, cantando e dançando alegremente, ao som de tamborins e címbalos".

-(I Samuel 18,7) "E enquanto dançavam, diziam umas às outras: Saul matou seus milhares, e Davi seus dez milhares".

-(I Samuel 29,5) "Não é ele porventura aquele Davi, do qual se cantava dançando: Saul matou seus milhares, e Davi seus dez milhares?”.

-(II Samuel 6,5) “Davi e toda a casa de Israel dançavam com todo o entusiasmo diante do Senhor, e cantavam acompanhados de harpas e de cítaras, de tamborins, de sistros e de címbalos”.

-(II Samuel 6,14) "Davi dançava com todas as suas forças diante do Senhor, cingido com um efod de linho".

-(II Samuel 6,16) "Ao entrar a arca do Senhor na cidade de Davi, Micol, filha de Saul, olhando pela janela, viu o rei Davi saltando e dançando diante do Senhor, e desprezou-o em seu coração".

-(I Reis 18,26) "Eles tomaram o novilho que lhes foi dado e fizeram-no em pedaços. Em seguida, puseram-se a invocar o nome de Baal desde a manhã até o meio-dia, gritando: Baal, respondenos! Mas não houve voz, nem resposta. E dançavam ao redor do altar que tinham levantado".

-(I Crônicas 13,8) "Davi e todo o Israel dançavam diante de Deus, de toda a sua alma, cantando com acompanhamento de cítara, de harpas e tamborins, de címbalos e trombetas".

-(I Crônicas 15,29) "Quando a arca da aliança do Senhor entrava na cidade de Davi, Micol, filha de Saul, que olhava pela janela, viu que o rei saltava e dançava, e desprezou-o no seu coração".

-(Judite 3,10) "e o acolhiam com coroas e archotes, dançando ao som dos tamborins e das flautas".

-(Salmos 86,7) "E cantarão entre danças: Todas as minhas fontes se acham em ti”.

-(Salmos 150,4) "Louvai-o com tímpanos e danças, louvai-o com a harpa e a flauta”. 
-(Eclesiastes 3,4) "tempo para chorar, e tempo para rir; tempo para gemer, e tempo para dançar";

-(Cântico dos Cânticos 7,1) "Volta, volta, ó Sulamita, volta, volta, para que nós te vejamos. - Por que olhais a Sulamita, quando ela entra na dança de Maanaim?”.

-(Eclesiástico 9,4) “Não freqüentes assiduamente uma dançarina, e não lhe dês atenção, para que não pereças por causa de seus encantos".

-(Isaías 13,21) "as feras terão aí seu covil, os mochos freqüentarão as casas, as avestruzes morarão aí, e os sátiros farão aí suas danças".

-(Jeremias 31,4) "Reconstruir-te-ei, e serás restaurada, ó virgem de Israel! Virás, ornada de tamborins, participar de alegres danças”.

-(Jeremias 31,13) "Então a jovem executará danças alegres; jovens e velhos partilharão (o júbilo) comum. Transformar-lhes-ei o luto em regozijo, e os consolarei após o sofrimento e os alegrarei”.

-(Lamentações 5,15) "Fugiu-nos a alegria dos corações; nossas danças se converteram em luto".

-(São Mateus 11,17) "Tocamos a flauta e não dançais, cantamos uma lamentação e não chorais”.

-(São Marcos 6,22) “A filha de Herodíades apresentou-se e pôs-se a dançar, com grande satisfação de Herodes e dos seus convivas. Disse o rei à moça: Pede-me o que quiseres, e eu to darei".

-(São Lucas 7,32) "São semelhantes a meninos que, sentados na praça, falam uns com os outros, dizendo: Tocamos a flauta e não dançastes; entoamos lamentações e não chorastes”.

-(São Lucas 15,25) "O filho mais velho estava no campo. Ao voltar e aproximar-se da casa, ouviu a música e as danças”.

Considerando as evidências encontradas na Bíblia, o Israel antigo dançava com freqüência em diversas ocasiões. Miriam celebrou a libertação dos israelitas da escravidão egípcia dançando; Davi dançou com fervor perante a arca revelando a si mesmo diante do povo.

Distingui-se entre as danças hebraicas, as religiosas, executadas no templo e presentes nas festas de maio, na festa dos tabernáculos e na festa das colheitas, traz épocas marcantes. Os fatos sociais, desde os mais simples aos mais relevantes, eram comemorados com canto, música e muito freqüentemente com manifestações coreográficas, assim como as festividades agrícolas.

\subsubsection{Dança na Grécia}

Segundo Caminada (2008):

Foram os gregos que descobriram que a beleza de um corpo não é 
apenas o resultado de proporções corretas, mas também, de uma postura anatômica particular. A dança fazia parte do cotidiano dos gregos desde o nascimento, núpcias, banquetes e outros e eram considerados importantes para a educação, para o culto e para o teatro (CAMINADA, 2008 p.15).

Nas danças sagradas a mais destacada é os rituais Dionisíacos, ou deus Dionísio, o deus do despertar primaveril da vegetação, ou o deus do vinho, que aos poucos foi sofrendo modificações, de cerimônia litúrgica, tornou-se cerimônia civil. De sagrada passou a ser profana um exemplo bem típico era o cortejo, onde Dionísio era acompanhado por mênades² .

Há na História da Dança Grega, algumas citações de Filósofos.

Sócrates, séc. V a.C. reforça a quebra da unidade, pois para ele o corpo é um obstáculo à alma. Ela é imortal, imperecível. A razão é que permite ao ser humano transcender ao cotidiano, encontrar sentido em suas ações e criar valores morais. Em Platão, séc. IV e $\mathrm{V}$ a.C. criador da metafísica ocidental, novamente vemos a alma em oposição ao corpo: ela é eterna, pura, sábia; ele, mortal, impuro, degradante. O corpo é a prisão da alma, negando a ela sua realização. Para Aristóteles, séc. IV a.C., a alma dá forma ao corpo, constituindo a natureza humana; o corpo é a matéria à qual a alma dá forma e motricidade. Para ele o ser humano político e pensante ordena sua existência pela razão. (GONÇALVES apud FÁTIMA, 2001).

A pírrica, uma de suas danças mais significativas, fez parte obrigatória da educação do cidadão grego. Era dançada com armas e escudos de pau, simulavam o ataque e a defesa na batalha. Usavam túnicas vermelhas, cinturões guarnecidos a aço e capacetes emplumados. Uma ótima preparação militar.

\subsubsection{Império Romano}

De acordo com Magalhães (2005) "Entre os Romanos, a Dança parecia ter um sentido mais claro e específico: Reis, República e Império”. Na época dos Reis a dança era praticada como rito religioso, de origem agrária. Um dos rituais mais conhecidos era Saliano, uma dança guerreira, praticada com freqüência durante a primavera em honra de Marte (o mês do

\footnotetext{
${ }^{2}$ Mênades: eram mulheres seguidoras e adoradoras do culto de Dioniso. Origem: Wikipédia, a enciclopédia livre.
} 
nascimento da primavera).

Com o início da República as danças foram ficando esquecidas e houve quem contribuíssem com isso como: Capitão Emiliano e Cícero que afirmavam que a dança era um sinal de insanidade, fecharam escolas que ensinavam dança as crianças de boa família. Só as tradicionais dança, como as núpcias, prevaleceram na cultura romana. A dança voltou a ser praticada durante o império, por mulheres de classe alta, mas é nas danças jogos de circo que se obteve mais sucesso (MAGALHÃES, 2005).

Nessa época a dança já havia sofrido modificações, não eram mais danças sagradas, perdeu-se muitos movimentos e denotações, na qual se aproximava mais da indecência, a dança dos banquetes é um exemplo e era praticada por bailarina profissional e tocadores de aulos (espécie de flauta doce). De acordo com Magalhães (2005) as Danças de banquetes eram provocantes e muitas vezes faziam uso de acrobacias. As bailarinas trajavam roupas especiais que deixassem à mostra partes pudicas do corpo, como seios, coxas e nádegas (Figura 02).

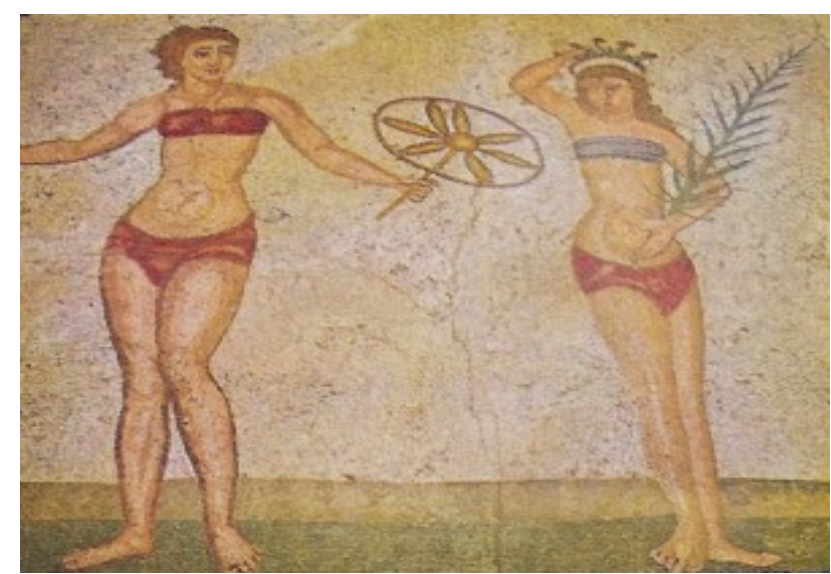

Figura 2 - Estampa de figuras humanas em jarro típico

FONTE: http://www.centroartisticodedanca.com.br/site_novo/pagi nas/historia.asp\#hebraica

\subsection{Idade Média}

Durante a Idade Média a dança foi proibida pela Igreja Católica, pois algumas apresentavam movimentos muito sensuais. Em seus estudos Garaudy (1980, p.28) cita que "Os padres da Igreja, Santo Agostinho entre eles, condenaram 'esta loucura lasciva chamada dança, negócio do diabo". 
Amaral (2008) em seu artigo mostra os testemunhos mais interessantes sobre a proibição da dança na Idade Média:

O mais antigo é o do concílio de Vannes, em 465. Entre os anátemas que se sucederam, podemos destacar os do concílio de Toledo em 587, o decretal do papa Zacarias em 774 contra os "movimentos indecentes da dança ou carola", a homilia do papa Leão V que condenava, em 847, "os cantos e carolas das mulheres na Igreja”. No final do século XII, as constituições sinodais do bispo de Paris, Odon ( Constitution, 36), prescrevem ao clérigo que proíba os choreae, "principalmente em três lugares: nas Igrejas, nos cemitérios e nas procissões”. Serão retomadas pelas instruções de Gerson (De visitatione prelatorum ): "se os leigos e mulheres entrarem no coro e trouxerem carolas aos lugares sagrados". Em 1209, o concílio de Avignon decreta (Atos, V): "Durante a vigília dos santos, não deve haver nas Igrejas espetáculos de dança ou de carolas". Em 1444, a Sorbonne, por sua vez, declara: "Não é permitido dançar carolas nas Igrejas durante a celebração do serviço divino". Em 1562, em sua reorganização da Igreja, o concílio de Trento sente-se obrigado a adotar estas regras (AMARAL, 2008. p. 5).

Mesmo com as proibições, muitas pessoas dançavam nas feiras, nas aldeias, nas comemorações e em momentos de festa. Eles dançavam Carola chorea $^{3}$ e o tripudium $^{4}$, danças ao som de cantos gregorianos ${ }^{5}$, e ritmados com tambores e tamborins. Eram danças populares e livres, dançadas por qualquer pessoa em ocasiões não religiosas.

Sobreviveram apenas as "danças macabras” que no século XIV conhecido como “século negro" por conta da peste negra uma epidemia que causou a morte de um quarto da população, o povo cantava e dançava nos cemitérios diante dos túmulos, acreditando assim que as encenações afastavam o demônio e impediam que os mortos saíssem dos túmulos e espalhassem a doença.

A morte da dança está no dualismo cristão onde São Paulo desprezou seu corpo Garaudy (1980, p.28) “o bem, no homem, só está na alma, e todo mal vem da carne traz como

\footnotetext{
${ }^{3}$ Chorea era a dança de roda fechada ou aberta, muito praticada, sob o nome de carola (AMARAL, 2008).

${ }^{4}$ Tripudium era uma dança em três tempos, na qual os executantes não se tocavam. (AMARAL, 2008).

${ }^{5}$ Canto Gregoriano é um gênero de música vocal monofônica, monódica (só uma melodia), não acompanhada, ou acompanhada apenas pela repetição da voz principal. Origem: Wikipédia, a enciclopédia livre.
} 
conseqüência a consideração do corpo como obstáculo à vida da alma e a orientação da vida para um outro mundo".

\subsection{Idade Moderna}

“Uma das idéias principais de François Delsarte era a de que não havia nada mais feio do que um gesto sem significado" (GARAUDY, 1980, p.81). Considerado pai da Dança Moderna, François Delsarte nasceu na França em 1811, nunca se interessou pela dança que na sua época não tinha valor, mas dedicou sua vida as leis da expressão corporal. Para ele "toda expressão é a tensão e o relaxamento dos músculos. Por exemplo, a extensão de todo o corpo está relacionada ao sentimento de auto-realização, e ao dobrar o corpo traduz o sentimento de anulação. Cada sentimento tem sua própria tradução corporal” (GARAUDY, 1980, p.81).

Bregolato (2000, p.140) relata que "Delsarte coloca os princípios existentes entre o espírito e o corpo, entre o pensamento e o gesto. Ele percebe que o movimento é a expressão da alma”.

Outro precursor da Dança Moderna é Emile Jaques Dalcroze, compositor e pedagogo suíço, que segundo Bregolato (2000, p.140) "Dalcroze cria a Rítmica, que permite adquirir o senso musical no ritmo corporal. Seu método preconiza o desenvolvimento musical do corpo”.

Os ideais de Delsarte começam a ser colocado em prática por Isadora Duncan (dançarina moderna) que trouxe uma nova técnica, diferente da clássica que havia passos e movimentos. Sem entender o porquê de cada passo, de cada movimento, Isadora cria uma dança Livre na qual usava os movimentos para expressar emoções. Em suas apresentações Isadora dançava com os pés descalços e o corpo coberto por túnicas soltas tentando transmitir a beleza dos movimentos livres do corpo (Figura 03a).

Bregolato (2000, p.137) “preconizava que a dança não devia ser a repetição de passos já instituídos. Devia ser livre e expressar os sentimentos mais íntimos do bailarino”.

Figura também importante na Dança Moderna é Martha Graham, americana, que

estudou na Denishawnschool (primeira escola que trabalhava com a Dança Moderna). É considerada a criadora da Dança Moderna no continente americano e uma de suas principais técnicas é a Tension-release (tensão-relaxamento) que segundo Bregolato (2000, p.139) para Martha "quando o movimento (contração) tem uma pausa (relaxamento), não há uma 
descontração total, pois mesmo no intervalo de um movimento para o outro é preciso equilibrar o corpo" (Figura 03b).
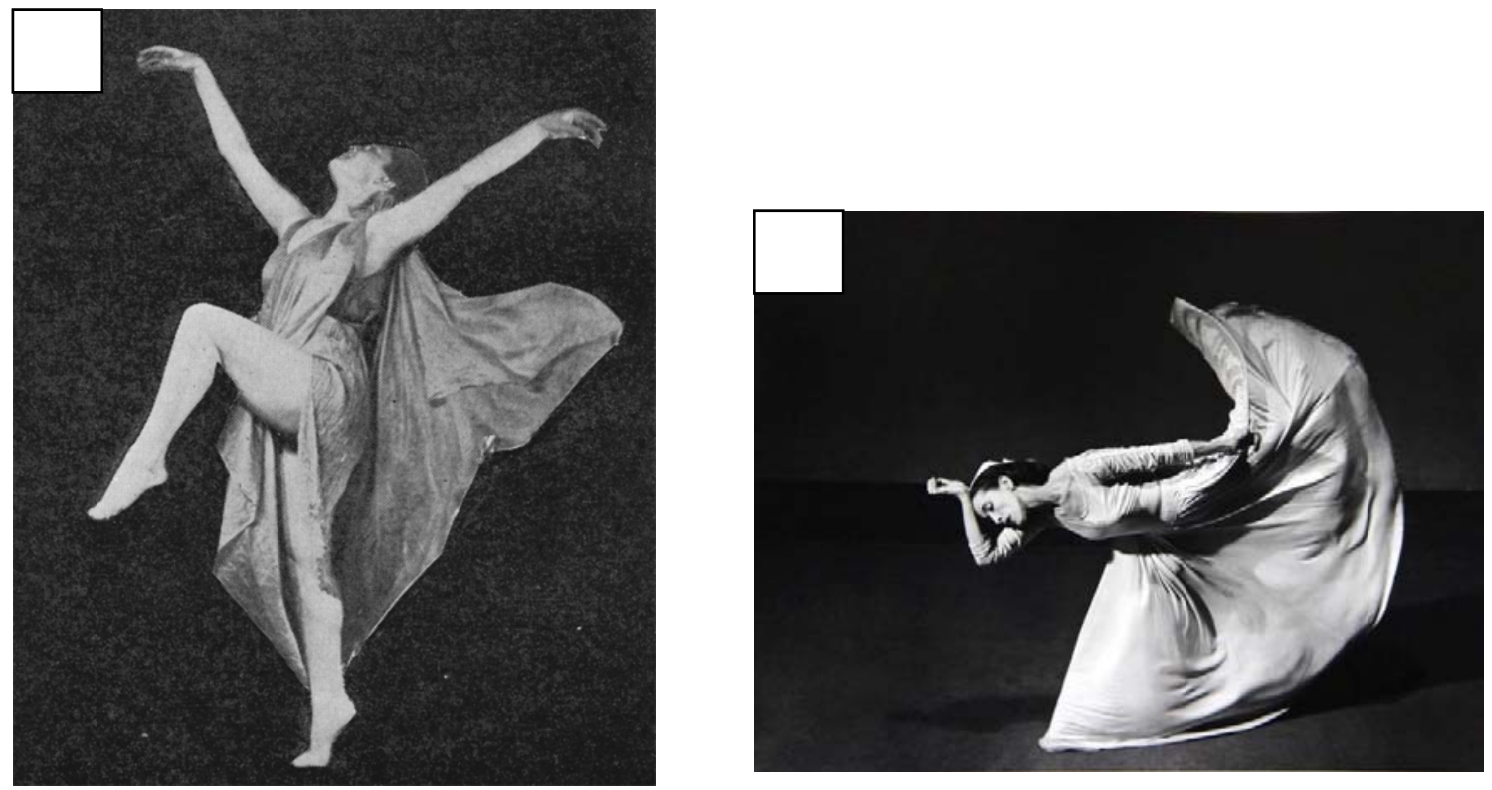

Figura 3 - (A) Isadora Duncan (dançarina moderna) Fonte: http://www.musikine sis.com/ID4.gif; (B) Martha Graham Fonte: http://www.afterimagegallery.com/ morgankick.jpg.

\subsection{Dança no Brasil}

Para entender como chegou à dança no Brasil, é preciso primeiro conhecer a história deste país e seus colonizadores, como foi influenciado por seus descobridores, etc.

Em 1500, chega ao Brasil cerca de 13 navegações portuguesas comandadas por Pedro Álvares Cabral. Eles andavam em busca de metais preciosos que num primeiro momento não conseguiram encontrar. Encontraram apenas o Pau-Brasil que foi bastante exportado para a Europa. Para conseguir o Pau-Brasil os colonizadores trocavam com os índios (primeira etnia brasileira) roupas, espelhos e outras bugigangas.

Só em 1530, começa a definitiva colonização gerando conflitos com os índios, pois queriam transformá-los em escravos. Foi por essa resistência indígena que os europeus foram obrigados a trazer da África o negro para as atividades da lavoura. 
Ao estudarmos a história do Brasil, nos é dito que nosso povo é a soma de três raças tristes: o português, o índio e o negro. Se temos aí a base de nossa população, não há dúvida de que o grande influxo de imigrantes de origem sobretudo européia influiu decisivamente em nossos costumes e nosso folclore, que variam enormemente de uma região para outra, muitas vezes em razão dos grupos de imigrantes que nelas se localizam.

Somos hoje o resultado uma salada racial onde descendentes de alemães, italianos, espanhóis, portugueses, japoneses ucranianos e árabes vieram somar à nossa vida, uma parcela de seus usos e costumes. Nossa herança folclórica é o resultado direto de todas essas influências. (FARO, 1986, p.24).

Os folcloristas classificam as danças brasileiras por suas origens (PINTO, apud BREGOLATO, 2000, p.92):

a) de inspiração ameríndia (indígena americana) como caboclinha, caipó, cateretê, e caruru ou cururu;

b) de inspiração européia (espanhóis, holandeses, portugueses) como bumba-meu-boi, cana verde, chegança, quadrilha, chula, são gonçalo, flamenga, fandango e frevo;

c) de inspiração africana como baião, batuque, coco, jongo, maxixe, samba, congada, lundu, maracatu e moçambique (PINTO, apud BREGOLATO, 2000, p.92).

De acordo com Nanni (1995 p.77) “as danças folclóricas brasileiras possuem características regionais. Dependendo da influência ética do lugar, ela terá mais aspectos indígenas como nos estados do Pará e Amazonas; africanos como na Bahia, Minas e Rio; ou europeus como nos estados do sul do país”. 


\section{CONCEITO DE DANÇA}

Há diversos autores que define a dança, na investigação bibliográfica. "É sempre difícil definir a dança, pois corremos o risco de reduzi-la em estilos ou estratificá-la no tempo e no espaço" (CHIARION, 2008).

Para Nunes apud Calazans; Castilho; Gomes (2003, p. 37): “dançar é aprofundar o sentimento e o conhecimento da vida do corpo retratado por experiências sensoriais, imagéticas, emotivas, impregnadas do saber dos sabores”. Gomes apud Calazans; Castilho; Gomes (2003, p. 109) diz que "a dança permite materializar o movimento da vida, e, por isso, adquire diferentes formas, ritmos e intensidades conforme a época, as influências culturais e as tendências pessoais".

Outro conceito é relatado por Figueiredo, Tavares, Venâncio (1999) que fala que a dança:

É uma arte e, como tal, nos permite que cada momento seja um ato criativo. Através dela podemos entender o instante e, então, percebemos a mutação de vida. A essência na dança é sempre original, no sentido que somos um corpo em presença no mundo, somos todos dançarinos, pois expressamos pelo corpo aquilo que somos; a dança não faz distinção ou opressão nós é que fazemos (FIGUEIREDO; TAVARES; VENÂNCIO, 1999. p. 25).

Já Garaudy (1980, p.14) diz que "a própria palavra 'dança’, em todas as linguagens européias - danza, dance e tanz -, deriva da raiz ‘tan’ que, em sânscrito, significa ‘tensão’. Dançar é vivenciar e exprimir, com máximo de intensidade, a relação do homem com a natureza, com a sociedade, com o futuro e com seus deuses”.

Para Peto (2000) a dança é “um exercício físico lúdico, que exerce um efeito de alto massagem em duplo sentido através de contrações musculares”. Vianna apud Fiório (2008) dançar é “expressar por meio de movimentos e formas nossos mais íntimos desejos. '...é aventurar-se na grande viagem do movimento que é a vida'”. 


\section{BENEFÍCIOS DA DANÇA}

A dança por ser uma atividade física aeróbia ela reduz os fatores de riscos de doenças cardiovasculares, os distúrbios do aparelho locomotor e até mesmo a depressão e ansiedade. Os objetivos da atividade física são vários, “como estimular o crescimento, e o desenvolvimento, hipertrofia muscular, flexibilidade, melhoria na capacidade cardiorrespiratória, alem de promover muitas descobertas dos próprios movimentos, alegria, motivação, sem esquecer-se da formação para o relacionamento social do indivíduo” (SILVA; FERREIRA, 2001). Essa sensação de bem estar está relacionada com a "liberação de endorfina, hormônio da felicidade” relato feito por um fisioterapeuta (BRANT, 2005), “uma substância que o cérebro produz que dá aos indivíduos a sensação de prazer” (McARDLE; KACTH; KACTH, apud GESTAL; MANSOLDO, 2008).

Durante o exercício aeróbio como é o caso da dança há uma queima de gordura excessiva que sai do corpo liberando o gás carbônico e água. Isso se faz, evidentemente, eliminando gorduras depositadas (reduzindo a absorção de calorias, o corpo é obrigado a utilizar as suas calorias de reserva) (PAVLOVIC, 1987 p. 29). Além da queima de gordura a capacidade pulmonar aumenta, pois há um grande consumo de oxigênio que durante o exercício aumenta a rede de pequenos vasos que irrigam os alvéolos pulmonares (estrutura de troca de gases), "melhorando o aproveitamento de oxigênio pelo pulmão. Desse modo, a respiração fica mais eficiente” (McARDLE; KACTH; KACTH, apud GESTAL; MANSOLDO, 2008).

Para Wilkstrom apud Chiarion, 2007 “os benefícios sociais da dança e atividade física estão interligados aos biológicos e psicológicos. Dentre os aspectos terapêuticos da dança aeróbia estão os relatos conscientes da melhoria do humor, diminuição da depressão e do estresse”, dando sustentação, força e sentido aos pronunciamentos verbais e posições no espaço que o homem executa ao se relacionar com o grupo (GAIARSA apud PETO, 2000). “A dança deve ser utilizada para auxiliar a aquisição e manutenção da saúde, aptidão social, mental, psíquica e física” (SASSARI apud CHIARION, 2008), propiciando o aumento da força muscular e do equilíbrio. (SHIGEMATSU et. al., apud CHIARION, 2008).

A fisiatra Cláudia Fonseca, presidente da Sociedade Brasileira de Medicina Física e Reabilitação, revela que a medicina realmente recomenda a dança, justamente por ser uma atividade 
extremamente prazerosa e capaz de proporcionar um condicionamento físico muito bom. A médica enumera os benefícios: melhora da capacidade cardiorrespiratória, diminui a pressão arterial, melhora a circulação periférica, perda calórica, fortalecimento muscular, proteção das articulações, atenua as dores e pode prevenir problemas futuros posturais e de artrose. 'Sem contar com os efeitos psicossociais, já que possibilita um aumento do convívio social, podendo ajudar a desinibir, além de relaxar'. (BRANT, 2005 p.A3) 


\section{SÍNDROME DE DOWN}

A Síndrome de Down ou Trissomia 21 é causada por um distúrbio genético apresentando na maioria dos casos um cromossomo 21 extra que não depende de classe social, raça, credo, ou clima.

\subsection{Histórico}

Os primeiros trabalhos científicos sobre a Síndrome de Down são bastante recentes, mas isso não significa que a Síndrome de Down inexistia em tempos anteriores. Referências claras a indivíduos com Síndrome de Down podem ser encontradas na cultura dos Olmecas, (SCHWARTZMAN, 1999, p. 3) um dos primeiros povos da mesoamérica que viveram na região atualmente conhecida como Golfo do México, de 1500 a.C até 300 d.C.

Dentro da cultura dos Olmecas arqueólogos encontraram gravações, esculturas e desenhos de crianças e adultos com características tais que fazem supor que fossem portadores da Síndrome de Down (Figura 04).

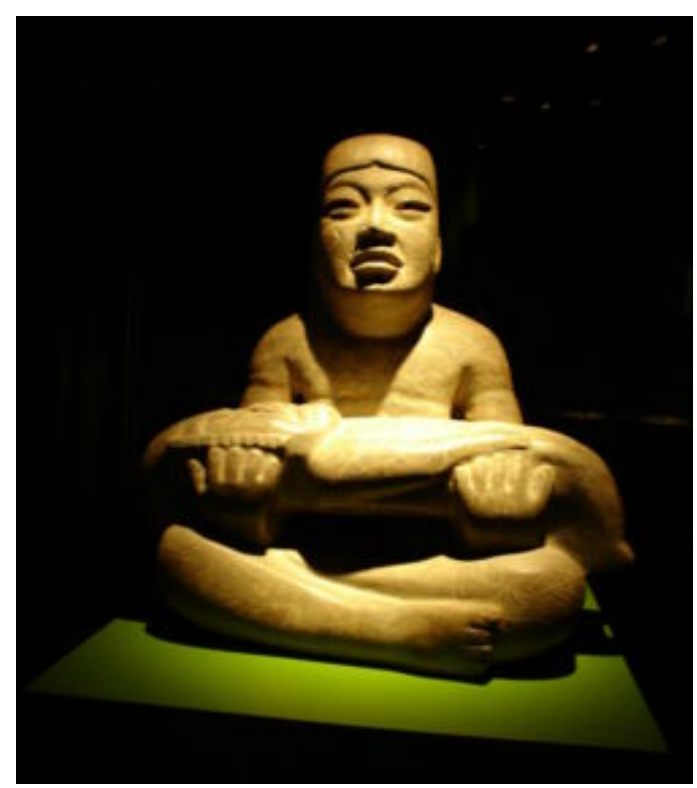

Figura 4 - El Señor de Las Limas.

Fonte:http://upload.wikimedia.org/wikipedia/commons/t humb/6/6b/Las_Limas_Monument_1_(O_Cadena).jpg/ 
Dados históricos sugerem que os Olmecas aceitavam que esses indivíduos com Síndrome de Down resultassem do cruzamento das mulheres mais idosas da tribo com o jaguar, este último objeto de culto religioso. Desta forma, a criança com Síndrome de Down era considerada um ser híbrido deus-humano e aparentemente cultuado como tal (SCHWARTZMAN, 1999, p. 3).

Já nas sociedades européias mais antigas as pessoas portadoras de deficiência tinham pouca importância, os bebês eram abandonados para morrer de inanição ou para serem devorados por animais selvagens. Os gregos em especial não toleravam os deficientes, eles justificavam tais atos cometidos falando que essas criaturas não eram humanas, mais um tipo de monstro pertencente a outras espécies, para eles, não havia diferença entre portadores de deficiências mentais para os doentes mentais. Os indivíduos "privados” que em grego eram chamados de “idiotas”. Este termo era associado aos fracos e portadores de deficiência e foi utilizado recentemente em textos de medicina para referir-se a deficiência mental.

Lutero, assim como a maioria que viveu na Idade Média não aceitava os portadores de deficiência considerando-os como produto da união entre uma mulher e o demônio. Na qual propunha que a criança deficiente e sua mãe fossem queimadas por causa dessa união malévola. Havia algumas exceções, assim segundo Brothwel apud Schwartzman, (1999, p.4) "Santo Agostinho parece ter conseguido que vários monastérios cuidassem de crianças defeituosas. Um destes monastérios situado na Inglaterra, escavações demonstraram a presença de um crânio que pertencia, pelas suas características, a uma criança de nove anos de idade com Síndrome de Down”.

Durante a Renascença, período das artes e dos pintores, encontra-se trabalhos de vários artistas que retratam diversos exemplos de deformidades físicas (Figura 05). Um deles é Brueghel 1525-1569) com pinturas freqüentes de aleijados e deformados.

Andréa Mantegna (1431-1506) pintou uma Madona e a Criança em que a criança representava Jesus e têm várias características da Síndrome de Down, e neste quadro a Madona retratada teria tido como modelo a mãe natural da criança. A criança poderia ser a filha de Bárbara de Brademburgo, da família dos poderosos Gonzaga de Mantua, dos quais Mantegna era o pintor da corte. Consta, também, que um dos quatorze filhos de Mantegna seria, também, portador da Síndrome de Down. É possível que o fato de o pintor ter um filho igualmente afetado pela Síndrome de Down tenha contribuído, ao menos em parte, para que ele fosse o escolhido para ser pintor da corte. Segundo Stralford (1996), esta poderia ser a primeira 
associação de famílias de portadores da Síndrome de Down de que temos notícia (SCHWARTZMAN, 1999, p. 6-7).

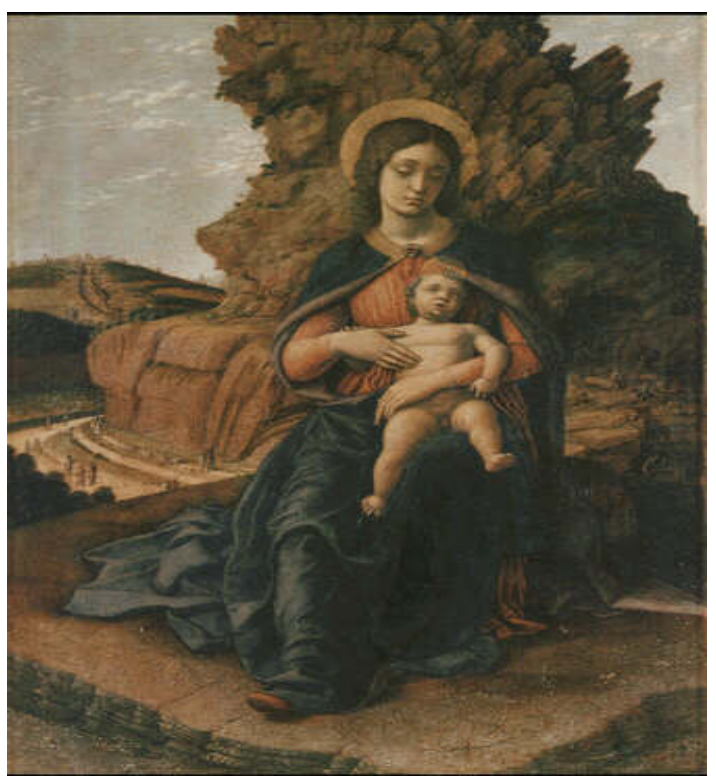

Figura 5 - Madona e a Criança

Fonte: http://www.virtualuffizi.com/uffizi/img/1348.jpg

John Langdon Down nasceu na Inglaterra, e foi o primeiro a descrever a Síndrome de Down, trabalhou no "Asilo para Idiotas", na Inglaterra e "ajudou a difundir o conceito da Síndrome de Down como uma entidade clínica peculiar e a diferenciá-lo do hipotireoidismo congênito ou cretinismo”. (SCHWARTZMAN, 1999, p. 7):

A grande família Mongólica apresenta numerosos representantes e pretendo neste artigo chamar atenção para o grande número de idiotas congênitos que são Mongóis típicos. O seu aspecto é tão marcante que é difícil acreditar que são filhos dos mesmos pais... O cabelo não é preto, como em um Mongol típico, mas de cor castanha, liso e escasso. A face é achatada e larga. Os olhos posicionados em linha oblíqua, com cantos internos afastados. A fenda pálpebra é muito curta. Os lábios são grossos, com fissuras transversais. A língua é grande e larga. O nariz, pequeno. A pele, ligeiramente amarelada e com elasticidade deficiente. É difícil acreditar que se trate de um europeu, mas pela freqüência com que estas características são observadas, não há duvida de que estes aspectos étnicos resultam de degeneração. O tipo de idiotia Mongólica ocorre em mais de 10\% dos casos que tenho observado. São sempre idiotas congênitos e nunca resultam de acidentes após a vida uterina. Eles são, na maioria, exemplos de degeneração originada de tuberculose nos pais. (DOWN, 1866 apud MOREIRA; EL-HANI; GUSMÃO 2000, p.96). 
Antes que Langdon Down descrevesse a Síndrome de Down como uma entidade clínica e emprestasse seu sobrenome, esses deficientes eram denominados como: imbecilidade mongolóide, idiotia mongolóide, cretinismo furfuráceo, “criança mal-acabada”, “criança inacabada” (SCHWARTZMAN, 1999, p. 13).

Em 1932, o oftalmologista holandês Waardenburg, deu a sugestão que a Síndrome de Down poderia ocorrer de um erro ou anormalidade cromossômica. Em 1934, nos EUA, Adrian Bleyer sugeriu que esse erro ou anomalia poderia ser uma trissomia. Só em 1956, Tijo e Levan determinaram que a espécie humana teria 46 cromossomos e esse seria o número normal dessa espécie.

Só mais tarde, em 1958, o francês Jerome Lejeune estudou os cromossomos de nove pessoas com Síndrome de Down e descobriu que as pessoas descritas pelo doutor John Langdon Down caracterizava um erro na distribuição dos cromossomos das células, que ao invés de 46 cromossomos por células agrupadas em 23 pares, tinham 47 cromossomos, um a mais no par de número 21. Essa seria a Trissomia 21.

Outra causa da Síndrome de Down é o mosaicismo descoberto por Clarke e colaboradores em 1961, eles descreveram os primeiros pacientes mosaicos.

Naquela época, o termo “mongolóide”, até em tão de uso corrente, começou a ser criticado por investigadores japoneses e chineses e pelos pais das crianças afetadas que o consideravam ofensivo. A delegação mongólica que compareceu a uma reunião da Organização Mundial da Saúde solicitou, informalmente que o termo não fosse mais utilizado. Publicações do Lancet, em 1964, da OMS, em 1965, e do Index Médicus, em 1975, suprimiram o termo de tal forma que ele é, hoje, considerado arcaico e pejorativo (HOWARD-JONES, apud SCHWARTZMAN, 1999, p. 15).

\subsection{Causas e Genéticas}

O nosso corpo é formado por pequenas unidades chamadas células. Dentro de cada uma, estão os cromossomos, que são responsáveis por todo o funcionamento da pessoa e determinam suas características (CASARIN, 2008).

A ciência já mostrou que o ser humano possui 46 cromossomos dispostos em ordem decrescente de tamanho, em 23 pares homólogos (SILVA; FERREIRA, 2001). 
As únicas células que não contem 46 cromossomos são o espermatozóide e o óvulo, coletivamente chamados gametas ou células germinais. Nos primeiros estágios do desenvolvimento, os gametas se dividem como todas as outras células (em um processo chamado mitose), com cada conjunto de 23 pares de cromossomos se duplicando. No entanto, na etapa final da divisão dos gametas, chamada meiose, cada nova célula recebe apenas um cromossomo de cada par original. Assim, cada gameta tem apenas 23 cromossomos, em vez de 23 pares. Quando uma criança é concebida, os 23 cromossomos do óvulo e os 23 do espermatozóide se combinam para formar os 23 pares que serão parte de cada célula do novo corpo que está se desenvolvendo. (BEE, 2003, p. 68).

Em alguns casos, durante o processo de divisão celular, há uma má distribuição de cromossomos, ou seja, segundo Bee (2003, p.79) “o material genético contém erros provocados por uma meiose imperfeita do espermatozóide ou do óvulo, resultando na falta ou no excesso de cromossomos” que varia de indivíduo para indivíduo, resultando nas anomalias.

Das anomalias identificadas a Síndrome de Down é a mais comum e se encontra dentro das deficiências mentais causadas por um acidente biológico (KAPLAN, SADOK apud ORNELAS, SOUSA, 2001) com que esse indivíduo fique com 47 cromossomos em cada célula, sendo três no par 21. Isto é, a criança down apresenta o cromossomo extra nas células de seu organismo e é esse cromossomo que produz as alterações no seu desenvolvimento físico e mental (LEFEVRE, apud ORNELAS; SOUSA, 2001) (Figura 06).

Encontram-se três tipos de cariótipos em pessoas portadoras da Síndrome de Down, a mais encontrada é a trissomia 21 em 96\% dos casos, que é causada pela presença de um cromossomo extra no par 21 em excesso resultante da não disjunção meiótica durante a formação dos gametas. Um outro tipo é a translocação, que corresponde a 2\% das pessoas com Síndrome de Down. Neste caso um cromossomo do par 21 está unido a outro cromossomo (geralmente o 15). Wernech (1993) acrescenta que esta pode ocorrer durante a formação do embrião ou estar presente em um dos pais, embora eles não sejam portador da Síndrome de Down (ORNELAS; SOUSA, 2001). Corresponde também a 2\% da população com Síndrome de Down o mosaicismo, o qual evidencia que a partir de uma trissomia simples ou de uma translocação, nem todas as células se multiplicam com cromossomo a mais. Algumas ficam com 46 e outras com 47 cromossomos, distribuídas em proporções diferentes pelo organismo (BONFIM apud ORNELAS; SOUSA, 2001). 


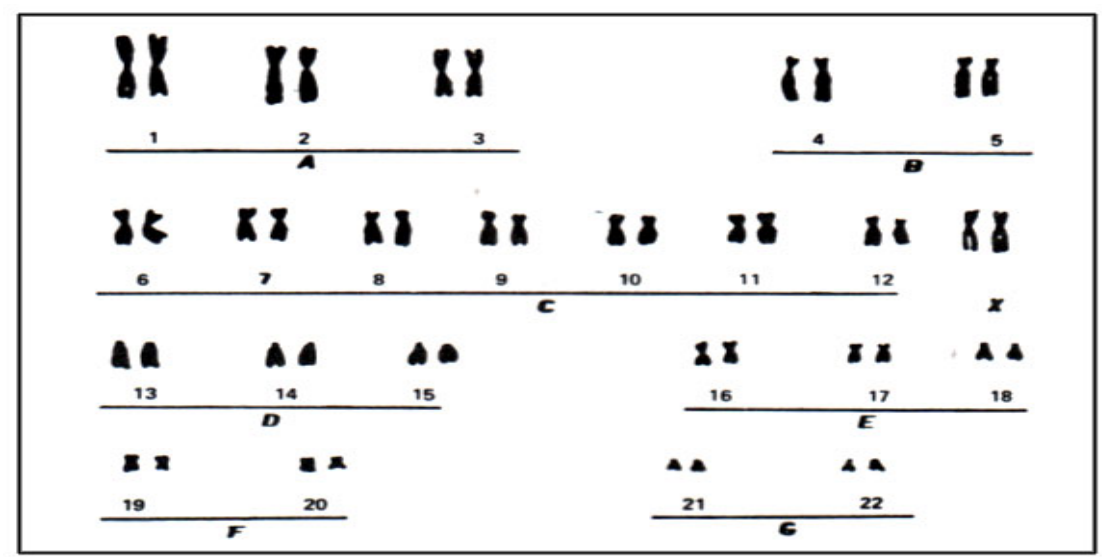

FIG. 38 - Cariotipo montado a partir da fotografia acima, célula normal com 46 cromossomos.

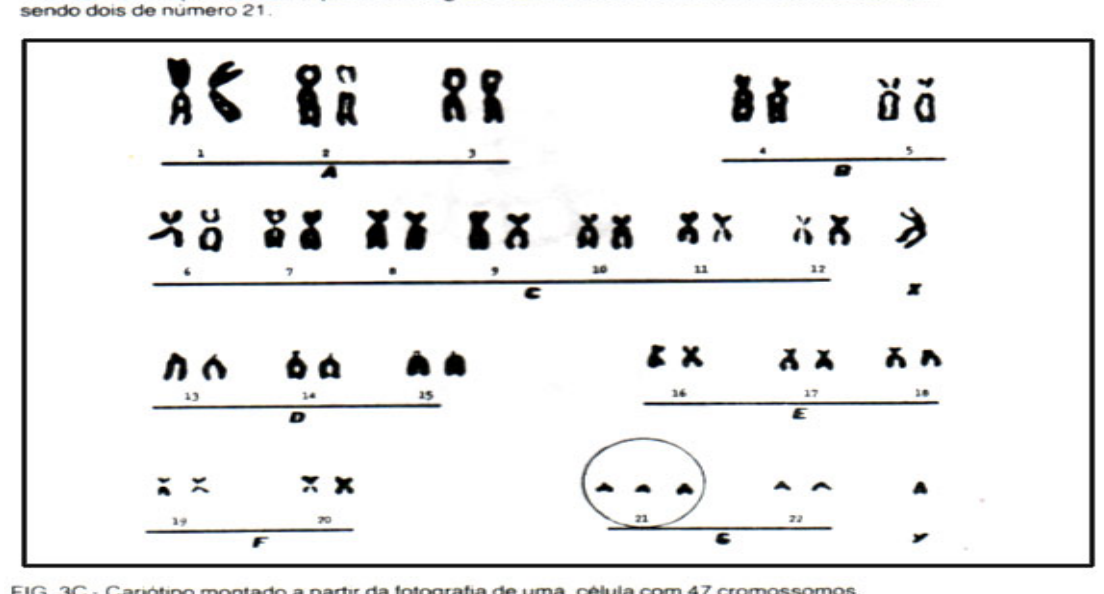

FIG. 3 C. Cariotipo montado a partir da fotografia de uma celula com 47 cromossomos.
sendo três de numero 21 (trissomia 21)

Figura 6 - Cariótipo

Fonte: Batista et. al.., (2008), Disponível em: http://www.projetodown.org.br

Estudos relatam que todos os casos de Síndrome de Down ocorrem devido a um erro ligado à divisão celular -a não disjunção - formando um enigma em torno dessa anomalia. Diversos autores citam que há uma probabilidade maior de pais expostos a agente lesivos geneticamente tais como um vírus, raios-X ou exposição química, pais com defeitos nos cromossomos e mulheres com idade gestacional avançada.

Em qualquer um dos casos, nada pode ser feito para impedi-la, mas é possível preveni-la por meio de aconselhamento genético e exames como volocorial, feito após nove semanas de gravidez, com amostras de células do ponto no qual se desenvolverá a placenta, e o amniocentese, feito com o líquido que preenche a placenta, realizado entre a $16^{\mathrm{a}}$ a $18^{\mathrm{a}}$ semana de gestação. (ORNELAS; SOUZA, 2001, p. 10) 


\subsection{Incidência e Prevalência}

“Entende-se por prevalência o número de indivíduos que apresentam uma determinada condição por número de habitantes, enquanto que incidência refere-se ao número de indivíduos afetados por números de nascimentos” (SCHWARTZMAN, 1999, p.20).

Com base em Zellweger apud Schwartzman (1999, p.20) a “incidência, na maioria dos países, seria de um para 800/1.000 nascidos vivos, e a prevalência de um para 2.000/3.000”. Segundo Dados do Instituto Brasileiro de Geografia e Estatística (IBGE), no último censo de 2000 informa que existem 300 mil pessoas com Síndrome de Down no país, tendo uma média de 8.000 novos casos por ano no Brasil, com expectativa de vida de 50 anos, sendo esses dados bastante semelhantes às estatísticas mundiais (SCHWARTZMAN, MOELLER, apud SILVA, KLEINHANS, 2006).

\subsection{Características da Síndrome de Down}

É de suma importância lembrar que o cromossomo extra exercerá influência de forma semelhante na formação do corpo desses indivíduos. Assim as crianças com Síndrome de Down apresentam muitas características em comum, e se parecem entre si (LIMA et. al.. apud ORNELAS; SOUSA, 2001), “essas crianças possuem um rosto achatado, nariz pequeno (em muitas crianças, passagens nasais estreitadas) e olhos um pouco oblíquos com uma prega epicântica na pálpebra, tamanho cerebral total reduzido e, com freqüência, outra anormalidades físicas”, (BEE, 2003, p.79) “como deficiência mental geralmente moderada, hipotonia muscular generalizada, pouca coordenação dos movimentos, língua protrusa, respiração bucal, cardiopatias (em 40\% dos casos), fala tardia, sensibilidade a infecções, hiperextensibilidade articular, frouxidão ligamentar da primeira e segunda vértebra cervical e outros”. (BONFIM, 1996 apud ORNELAS; SOUSA, 2001).

Damasceno (apud ORNELAS; SOUSA, 2001) “apresenta as características mais evidentes, as descoordenações motoras, lentidão na aprendizagem da marcha, da fala e dos cuidados pessoais. Não podemos deixar de salientar ainda a hipotonia, ou seja, a flacidez muscular e a instabilidade atlanto-axial, que estão ligadas diretamente”. Outras características encontradas em pessoas com Síndrome de Down é o espaço excessivo entre o hálux e o 
segundo dedo do pé, a flat nasal bridge, pontos brancos nas íris conhecidos como manchas de brushfield, pescoço curto.

A Associação Americana de Deficiência Mental (AADM) considera como deficiente mental àquela pessoa que possui o funcionamento mental abaixo da média, que se manifesta durante o período e desenvolvimento e se caracteriza pela inadequação da conduta adaptativa. No caso da Síndrome de Down, a deficiência mental é uma das características freqüentes, como parte de um quadro genético com patologia específica. (SILVA; FERREIRA, 2001, p. 12).

Kaplan; Sadok apud Silva; Ferreira, (2001) comentam que "o retardo mental está sempre presente nas pessoas com Síndrome de Down, pois o QI geralmente é menor que 50; as más formações cardíacas também são comuns em $40 \%$ dos casos”. 


\title{
7 DANÇA E A SÍNDROME DE DOWN
}

\begin{abstract}
A deficiência muitas vezes isola a criança do mundo tanto no que diz respeito a sua participação, quanto à compreensão dos fatos. A arte pode neste caso, assumir um importante papel como facilitadora de comunicação. Ela oferece à criança novas formas de expressão de suas idéias e sentimentos e ainda, possibilitar a aquisição de novos conceitos (MESQUITA; ZIMMERMANN, 2006 p. 21).
\end{abstract}

A dança poderá estimular no desenvolvimento global das pessoas com Síndrome de Down, integrando corpo e mente e proporcionando "novos instrumentos de comunicação de idéias e relações entre os indivíduos” (MESQUITA; ZIMMERMANN, 2006) e este trabalho vem mostrar que o portador de Síndrome de Down tem corpo imaginário que se caracteriza no corpo real e que esse corpo pode diferentemente realizar-se na dança. Isto acontece com a intenção de desmascarar o preconceito social, corporal e intelectual.

Os efeitos da dança para o portador de Síndrome de Down diminuirão suas limitações principalmente no que diz respeito ao retardo mental, desenvolvimento motor, hipotonia, alterações na coluna cervical, obesidade, etc. No prazer da dança poderá surgir à busca do desconhecido onde os portadores de Síndrome de Down encontrarão seus rostos por meio de sensação que irá mostrar-lhes a outra face do desconhecido: o corpo como meio de comunicação e como um fator de experiência no seu dia a dia sem privar-se.

Através da dança o portador da Síndrome de Down encontra e mostra uma nova linguagem diante dessa sociedade cheia de preconceitos, essa magia que vai passar a se significar como um corpo que fala, pensa e age. Diante dessa questão todos nós somos deficientes, não há aquele sem nenhum tipo de deficiência seja ela aparentemente ou não.

É sempre bom lembrar que a dança como qualquer outra atividade física "deve estar inserida dentro de um programa global de intervenção sobre os fatores de risco, a avaliação médica e atividade física deve ser realizada em ambiente supervisionado por profissional de saúde, apto a monitorar a freqüência cardíaca, pressão arterial e sintomas” (MIRANDA apud CHIARION, 2008). Isso não vai tirar ou colocar mais deficiência no estado em que se encontra, por isso, o profissional tem o dever de sempre respeitar a individualidade de cada um evitando que a dança se torne um fator de risco. 
A instabilidade de articulação atlanto-axial em crianças com Síndrome de Down, o que requer atenção redobrada em trabalhos de rolamentos, devendo-se também evitar movimentos bruscos com a cabeça.

Os problemas respiratórios e as cardiopatias, também muito comuns em portadores de Síndrome de Down, devendo-se evitar, portanto, atividades extremamente exaustivas, e estar sempre orientando o trabalho de respiração e compensação das articulações e músculos trabalhados.

Quadros de epilepsia, muito comuns em deficientes mentais, que exige do profissional, atitudes simples, como segurar a cabeça, no caso de alguma crise convulsiva (MESQUITA; ZIMMERMANN, 2006, p. 10).

De acordo com Figueiredo, Tavares, Venâncio (1999) a principal essência da dança está no sentido de que somos um corpo no mundo e que expressamos pelo corpo aquilo que somos; a dança não faz distinção ou opressão, nós é que fazemos. "Mas Dança não exclui ou escolhe um corpo, ela abriga e acolhe qualquer corpo, ela não o tem para que se cale e se submeta ao domínio daquele que possui. O corpo somos nós, e a Dança, nós a vivemos” (FIGUEIREDO, TAVARES, VENÂNCIO, 1999). 


\section{METODOLOGIA}

Tendo em vista o objetivo deste estudo, optou-se por realizar uma pesquisa qualitativa por considerar ser uma abordagem que permite ampliar a compreensão acerca da temática estudada. Foi encontrado respaldo para esta opção em MINAYO (2000).

A pesquisa qualitativa tem uma de suas raízes no campo da antropologia surgindo nos países da América Latina, na década de 70, devido a aspectos das pesquisas em educação. A partir daquela época, abriu-se caminho para outras áreas, incluindo o campo da saúde.

Segundo MINAYO (2000), a questão da pesquisa qualitativa faz eclodir um contexto teórico e prático, como um fenômeno de alta significação, deixando de ser uma linha de pensamento para ser um movimento social em busca de novos paradigmas para a educação.

Para ALVES (2000), o enfoque qualitativo permite aprofundar um processo de comunicação autêntica entre o pesquisador e os participantes pesquisados, tendo como conseqüências interações espontâneas saudáveis.

Dentro do enfoque qualitativo, voltou-se para o método exploratório descritivo (MINAYO, 2000). Este método é usualmente utilizado para obter mais informação em um particular campo de estudo. Seu propósito é fornecer uma perspectiva da situação como ela naturalmente acontece (BURNS, GROVE, 1995).

A pesquisa qualitativa enfoca a obtenção de dados que revelem valores, crenças, sentimentos, comportamento, significados, dentre outros, dos participantes pesquisados. Tem o ambiente natural como fonte de dados para a descoberta da natureza e das características de um fenômeno (ALVES, 2000).

Para a realização deste trabalho foi realizada uma pesquisa prática por meio de entrevistas com sete profissionais das seguintes áreas:

- HADS, Fisioterapeuta, 30 anos masculino;

- LRS, Musicoterapeuta, 35 anos, feminino;

- SRB, Fonoaudióloga, 37 anos feminino;,

- AOS, Terapeuta Ocupacional, 28 anos, feminino;

- CVLV, Psicóloga, 40 anos feminino;

- $\quad$ TJAA, Assistente Social, 45 anos, feminino;

- MSM, Educador Físico, 40 anos, masculino. 
Na coleta de dados utilizou-se de questionário com 10 perguntas tentando obter mais informações em relação à Síndrome de Down e suas capacidades sociais, emocionais e cognitivas visando uma abordagem global. Foi realizada observações da atuação desses profissionais em suas áreas.

A pesquisa foi feita dentro da Associação de Pais e Amigos dos Excepcionais (APAE) de Imperatriz, localizado na Rua São Francisco, s/n qd 10, no bairro Vila Lobão.

Pela multiplicidade e complexidade das alterações na maioria das áreas que afetam a Síndrome de Down, como a motora, clínica, física, emocional, intelectual e os problemas sensoriais, há necessidade de tratamento e intervenção interdisciplinar por profissionais que atuam nas áreas específicas integradas entre si. (SCHWARTZMAN, 1999, p. 182)

Segue questionário aplicado:

Questão 1. Defina o que é Síndrome de Down.

Questão 2. Quais as principais características da Síndrome de Down?

Questão 3. Como é realizado o diagnóstico de uma pessoa com Síndrome de Down?

Questão 4. Quais os principais pontos trabalhados com o portador de Síndrome de Down?

Questão 5. Qual o seu papel frente ao portador de Síndrome de Down?

Questão 6. Quais os principais comprometimentos que você vê no portador de Síndrome de Down? E destes quais são considerados recuperáveis ou não?

Questão 7. Como a relação da família pode auxiliar no desenvolvimento do portador de Síndrome de Down?

Questão 8. Que outros tipos de técnicas você indicaria para o portador de Síndrome de Down?

Questão 9. Quanto tempo de trabalho você considera importante no desenvolver para o portador de Síndrome de Down?

Questão 10. Para você qual a importância da Dança com o portador Síndrome de Down? 
Para organização da análise, seguiram-se as etapas operacionais da pré-análise, exploração e interpretação dos resultados, descritos por ALVES (2000). Como lembra esse autor, é na prática que se definem os procedimentos de análise, porém se faz necessário ultrapassar a incerteza e o perigo da compreensão espontânea e buscar a interpretação dos significados que estão inseridos nos meandros profundos dos conteúdos e das instituições não quantificáveis.

Considerou-se a análise do material coletado a partir da aplicação dos questionários, que possibilitou analisar a freqüência simples das questões, como também favoreceu caracterizar elementos constitutivos para compreensão interpretativa dos dados obtidos. Compreende-se esse momento como sendo o movimento individual, de reconhecimento de cada participante, de recolhimento, de introspecção, de reflexão, ou seja, do movimento de fora para dentro, do olhar para o interior. 


\section{RESULTADOS}

Apresentam-se neste capítulo, os resultados do estudo. A seguir, apresentam-se as concepções e percepções dos profissionais estudados acerca dos portadores de Síndrome de Down, obtidas nas análises dos dados.

\section{Questão 1. Defina o que é Síndrome de Down.}

Por ser um distúrbio genético todos os profissionais tiveram respostas semelhantes:

“É uma cromossomopatia, doença cujo quadro clínico global e explicado por um desequilíbrio na constituição cromossômica, a presença de um cromossomo 21 extra”. SRB Fonoaudióloga

"É a presença de um cromossomo 21 extra total ou parcialmente, causando um distúrbio genético. Essa Síndrome geralmente é identificada no nascimento”. AOS - Terapeuta Ocupacional

“Síndrome é um distúrbio que apresentam 47 cromossomos no núcleo de cada célula ao invés dos normais 46 herdados do pai e da mãe sendo 23 de cada um. Os cromossomos contêm a herança genética e o extra localiza-se no par 21”. MSM - Educador Físico

“A síndrome de Down (SD) é um distúrbio genético mais freqüente de retardo psicomotor causada por uma anomalia cromossômica microscopicamente demonstrável”. HADS - Fisioterapeuta

“È a presença de um cromossomo 21 extra é um atraso total do desenvolvimento, tanto das funções motoras do corpo como mentais”. TJAA - Assistente Social

“A Síndrome de Down não é uma doença, é uma alteração genética também conhecida como Trissomia do 21, justamente porque ao invés dos 23 pares de cromossomos, no par 21 existem três cromossomos. Pode ocorrer com qualquer pessoa independente de raça ou idade”, C V L V - Psicóloga

“É uma desordem genética que causa deficiência mental em graus variados. Atualmente, seu quadro clínico é bastante conhecido ”. L R S - Musicoterapeuta 


\section{Questão 2. Quais as principais características da Síndrome de Down?}

As características entre esses portadores são bastante evidentes e comuns entre si:

“Alterações endocrinológicas, Alterações cardiovasculares, Alterações oftalmológicas, Alterações imunológicas, Alterações esqueléticas, Alterações respiratórias, Mau oclusão, Distância aumentada dos olhos, Rebaixamento do conduto (Implantação baixa) auditivo, Diminuição das falanges, Hipotonia generalizada”. SRB - Fonoaudióloga

"Prega palmar transversa, olhos com formas diferenciada, tônus muscular pobre e língua protrusa, hipotonia (flacidez), comprometimento intelectual, defeitos cardíacos, etc”. AOS - Terapeuta Ocupacional

"Para os profissionais que vão trabalhar um Down é muito bom conhecer as características físicas para melhor executar o seu trabalho, são elas: Olhos - pálpebras estreitas levemente oblíquas. Íris - pequenas manchas brancas chamadas de manchas de Brushfield. Cabeça - geralmente menor e a parte posterior levemente achatada. Boca - pequena e muitas vezes se mantém aberta com a língua projetando-se para fora. Mãos - curtas e largas. Musculatura - de modo geral mais flácida. Orelhas pequenas e conduto auditivo estreito. Dedos dos pés geralmente curtos com espaço maior entre o dedão e o segundo dedo”. MSM - Educador Físico

"Há sinais físicos que acompanham a síndrome de down são eles: Hipotonia Abertura das pálpebras inclinadaa parte externe mais elevada prega das pálpebras como canto interno dos olhos como nas pessoas da raça amarela. por exemplo, japoneses de língua prontrusa para fora prega única na palma das mãos” TJAA - Assistente Social

"É um cromossomo extra na constituição cromossômica dos indivíduos com Síndrome de Down” CVLV - Psicóloga

“A síndrome de Down é uma cromossomopatia, ou seja, uma doença cujo quadro clínico global é explicado por um desequilíbrio na constituição cromossômica” LRS Musicoterapeuta

“É a presença de um cromossomo 21 extra caracterizando, assim, uma trissomia simples” HADS - Fisioterapeuta 


\section{Questão 3. Como é realizado o diagnóstico de uma pessoa com Síndrome de Down?}

Em relação ao questionário sobre o diagnóstico foram gerados alguns comentários: "Quando uma criança chega com a queixa de algum atraso ou dificuldade é realizado os seguintes procedimentos (no caso da APAE): a) Anamnese com todos os profissionais da equipe multidisciplinar; b) Logo o término de todas as avaliações da equipe, o mesmo é encaminhado para o Neurologista e outros profissionais que a equipe indica de acordo com a necessidade do paciente; c) O paciente no Neurologista realiza exames e retorna a instituição com o laudo e todos os exames neurológicos; d) A equipe coloca o seu parecer e seu suposto diagnóstico no prontuário que vai para o Neurologista através das avaliações físicas, da contextualização verbal, dos pais ou responsável, investiga se foi feito o teste do pezinho, investiga as características físicas da Síndrome e apresenta estímulos; e) Após todas as avaliações é marcado o dia e horário dos atendimentos e fornecido para o paciente que tem dificuldade financeira de se locomover um atestado para TCI proporcionar passe livre”. LRS Musicoterapeuta.

“O principal diagnóstico é do Neuropediatra após o cariótipo, o diagnóstico fonoaudiológico é avaliativo dos déficits motores, cognitivos e da linguagem”. SRB Fonoaudióloga

“O principal diagnóstico é Neuropediatra depois é feito o Diagnóstico cinesiofuncional Atraso no desenvolvimento neuropscicomotor, Hipotonia muscular geral. Padrão ventilatório normal”. M S M - Educador Físico

"É feito através do cariótipo que é a representação do conjunto de cromossomos de uma célula e também dos déficits motores, cognitivos e da linguagem”. TJAA - Assistente Social

“Geralmente é realizado pelos achados fenotípicos, ou melhor, pela aparência facial. De fato, é a associação de sinais discretos observados na face dos pacientes que permitem o diagnóstico, principalmente nos recém nascidos. Para não haver dúvidas, o diagnóstico definitivo é alcançado com o estudo cariótipo”. CVLV - Psicóloga

"O diagnóstico inicial Síndrome de Down deve ser holística, sendo importante estar alerta aos problemas associados à síndrome, tais como hipotonia, redução da força muscular, hipermobilidade articular, pés planos, escoliose, alterações respiratórias, instabilidade atlânto-axial, deficiências visual e auditiva”. HADS - Fisioterapeuta 
“Apesar das pessoas com Síndrome de Down tenham características físicas específicas elas têm mais semelhança do que diferença com a população em geral, mas nem sempre Síndrome de Down apresenta todas as características alguns podem ter só algumas delas, mas é muito importante para os médicos fazerem o diagnóstico:

- Inclinação das fendas palpebrais,

- Língua proeminente,

- Ponte nasal achatada,

- Boca pequena,

- Mãos e pés pequenos”. AOS - Terapeuta Ocupacional

\section{Questão 4. Quais os principais pontos trabalhados com o portador de Síndrome de Down?}

Neste questionário cada profissional respondeu de forma abrangente e na sua função específica:

\section{Musicoterapeuta:}

“O programa e método utilizado é a Estimulação Neurossensorial onde se trabalha na musicoterapia a estimulação das percepções com métodos e técnicas não-verbais como:

- $\quad$ Recreação musical terapêutica

- $\quad$ Musicoterapia perceptiva (audição específica)

- Musicoterapia ativa (exploração livre e direcionada com instrumentos

musicais)

- $\quad$ Exercícios sonoros

- $\quad$ Construção de instrumentos musicais de sons graves e de pequeno porte para manuseio do paciente em seu lar”. (LRS).

\section{Educador Físico:}

"Não somente com eles, mas com qualquer criança, basear-se-ia na psicomotricidade, jogos lúdicos e esportivos, jogos cooperativos, expressão corporal, no qual seria usado a dança”. (MSM) 


\section{Fonoaudióloga:}

"Estimulação cognitiva;

Estimulação a independência;

Estimulação a socialização onde a família deve adquirir conhecimentos e iniciativa para esta prática”. (SRB)

\section{Terapeuta Ocupacional:}

"Para o portador: As atividades desenvolvidas são: estimulação precoce, atividades para habilidades cognitivas, atividades para o desenvolvimento físico, atividades lúdicas, AVD’s (Atividades da Vida Diária), expressão corporal e outras.

Para a família: Orientação familiar para tornar o ambiente estável e condutor, explicar suas limitações, informar a importância da educação, participação dos mesmos dentro das atividades familiares para estimular seus esforços”. (AOS)

\section{Fisioterapeuta:}

“A intervenção precoce nos infantes com a síndrome indica que as limitações físicas e intelectuais destas podem ser modificadas por meio de manejo competente e do treinamento precoce da educação psicomotora que tem como objetivos: aquisição de domínio corporal, controle da inibição voluntária e desenvolvimento sócio-afetivo para modificar significativamente os padrões de aprendizagem. Podendo também melhorar o desenvolvimento sensório-motor e social da criança com a Trissomia do 21 e influenciar nos processos mais complexos de aprendizagem auditiva”. (HADS)

\section{Assistente Social:}

"É importante ressaltar que cada criança tem seu próprio ritmo de desenvolvimento, que deve ser percebido e respeitado auxiliá-la a alcançar as etapas sem tentar pular as etapas para adiantar o processo estimular desenvolvimento da forma mais adequada possível, buscando a funcionalidade na realização das atividades diárias e na resolução de problemas”. (TJAA) 


\section{Psicóloga:}

"Deve ter uma atenção a sua saúde, visando sempre sua melhor qualidade de vida, oque reflete-se diretamente com o projeto de lazer que lhes será oferecido, bem como a um programa dietético peculiar aos comprometimentos salutares específicos, como também a dieta rotineira bem balanceada. O mais importante é o programa de "lazer", ocupação que lhes é oferecida para sua ocupação e saúde mental”. (CVLV)

\section{Questão 5. Qual o seu papel frente ao portador de Síndrome de Down?}

Neste questionário cada profissional respondeu de forma abrangente e na sua função específica:

\section{Fonoaudióloga:}

"Estimular a musculatura oro - facial a melhorar tônus e postura

Estimular a adequação das FNV (Sucção, mastigação, respiração e deglutição)

Estimular a aquisição da linguagem oral e escrita”. (SRB)

\section{Terapeuta Ocupacional:}

"Estimular, orientar, apoiar, e organizar maior independência trazendo para o mesmo melhor qualidade de vida”. (AOS)

\section{Educador Físico:}

“Contribuir e estimular a inclusão na escolar regular do portador para um desenvolvimento mais humano integrando socialmente apesar das e diferenças físicas definidas pelo grupo sócio-cultural. A escola é instituição favorável a transformação social a partir dessa inclusão”. (MSM)

\section{Assistente Social:}

"Participar de reuniões com a equipe de profissionais da escola, sempre que necessário incentivar a participação dos pais no processo de desenvolvimento de seus filhos e na sua inserção de pessoas com Síndrome de Down no mercado de trabalho. Promover capacitações sobre temas relacionados a inclusão, nas escolas do Ensino Regular”. (TJAA) 


\section{Psicóloga:}

“Acompanhar o processo de aprendizagem avaliar a necessidade de intervenção do mesmo incentivar a participação dos pais no processo de desenvolvimento de seus filhos. Encaminha-los para atendimentos complementares, como: atendimentos clínicos psicoterapia psiquiatria e neurologia”. (CVLV)

\section{Fisioterapeuta:}

“Criar condições para explorar o potencial motor da criança, direcionando-a nas sucessivas etapas do desenvolvimento motor e auxiliá-la na aquisição de padrões essenciais e fundamentais do desenvolvimento, preparando-a para uma atividade motora subseqüente mais complexa”. (HADS)

\section{Musicoterapeuta:}

"É muito importante na condição de dar alicerces e estruturação para que a família consiga entender, compreender e acreditar na perspectiva da ampla gama de possibilidades que ornamentam a sociabilização dos portadores da síndrome de Down, desmistificando parâmetros sócio-culturais e informações impostas pela sociedade com relação as esses pacientes”. (LRS)

\section{Questão 6. Quais os principais comprometimentos que você vê no portador de Síndrome de} Down? E destes quais são considerados recuperáveis?

“O desenvolvimento da linguagem e aprendizagem nos portadores de Síndrome de Down severo, por conta do retardo mental acentuado”. SRB - Fonoaudióloga

“Os recuperáveis ao ponto de inclusão a todas as atividades e a sociedade, são aqueles de Síndrome de Down leve e moderado, os quais desenvolvem linguagem, aprendem se comunicar, se expressam podendo ter uma vida social tranqüila. Assim cantam e vibram com a vida”. LRS - Musicoterapeuta

“Deficiência intelectual, defasagem na aprendizagem motora e limitações físicas. Na deficiência intelectual existem limites de resultados, porem até alcançá-los dá para ter bastante progresso, o mesmo vale para as limitações ou defasagens na aprendizagem motora. Em todos sempre existirá algo para superarmos”. MSM - Educador Físico 
“Algumas pessoas com Síndrome de Down nascem com problemas cardíacos. Freqüentemente, esses problemas podem ser resolvidos por meio de cirurgia os atrasos de desenvolvimento psicomotor dificuldade no ritmo do aprendizado, tanto das atividades da vida diária como escolar. Mais o quadro pode ser mudado alcançando um progresso no trabalho cognitivo”. CVLV - Psicóloga

“Deficiência mental é a redução da capacidade intelectual e dificuldades ou nítido atraso em seu desenvolvimento neuropsicomotor. A Educação Inclusiva ajuda muito numa vida mais tranqüila, para a construção de conhecimentos e a garantia do direito de todos à educação". HADS - Fisioterapeuta

"Processo de inclusão dos Portadores de Síndrome de Down é ainda um problema nos dias de hoje, mas a inclusão vem mudando essa realidade tanto no meio escolar quanto na própria sociedade. Outra dificuldade encontrada são suas limitações, mas o portador da Síndrome de Down é capaz de compreender e conviver com suas dificuldades”. TJAA - Assistente Social

"Hipotonia, hiperflexibilidade articular, atraso motor são alguns dos comprometimentos encontrados na Síndrome de Down. Com atividades físicas ou mentais podese ajudar na recuperação e torna mais agradável proporcionando uma qualidade de vida melhor em seu meio sócio, psicoeducacional” AOS - Terapeuta Ocupacional

\section{Questão 7 Como a relação da família pode auxiliar no desenvolvimento do portador de Síndrome de Down?}

Observa-se que a família deve ser orientada de como tratar e lidar com o portador de Síndrome de Down, tendo assim um maior apoio e noções quanto às dificuldades existentes aprendendo a observar os aspectos positivos que possuem o portador de Síndrome de Down independentemente de suas limitações tratando-o como um dito "normal”.

"Uma participação ativa da família na vida da pessoa com Síndrome de Down é super importante para seu desenvolvimento e uma boa evolução terapêutica”. AOS - Terapeuta Ocupacional

“A família é o eixo de qualquer tratamento, principalmente em uma pessoa com Síndrome de Down, seja ela leve, moderada, severa, com retardo mental ou não, pois, a família deve dar continuidade aos exercícios sonoros e físicos, cantados ou ouvidos em casa, no 
momento do acordar, das alimentações, do banho, do brincar e dormir”. LRS - Musicoterapeuta

“A família deve promover a independência e socialização, mas com a consciência da necessidade do tratamento e terapias especializadas”. SRB - Fonoaudióloga

“Família é a principal influência para o desenvolvimento da personalidade da criança.” CVLV - Psicóloga

“O ambiente famíliar tem o papel muito importante no desenvolvimento psicológico cognitivo afetivo emocional motivacional e social da criança Síndrome de Down através da experiência vivida com várias pessoas da família seu desenvolvimento possa ocorrer sem falhas”. M S M - Educador Físico

“Os estímulos são de grande importância, pois devem favorecê-los e é, nesse ponto, que o empenho da família é fundamental” TJAA - Assistente Social

“A chegada de uma criança portadora de necessidades especiais apresenta inúmeras dificuldades para a família, mas é importante analisar as dificuldades dos pais de portadores de Síndrome de Down, mas sem esquecer que o deficiente precisa de uma criação muito bem planejada a família é o eixo assim poder desenvolver seu potencial e ser feliz apesar de suas limitações”. HADS - Fisioterapeuta

\section{Questão 8. Que outros tipos de técnicas você indicaria para o portador de Síndrome de Down?}

As técnicas usadas para melhorar ou estimular a Síndrome de Down são diversas entre as áreas que atuam com esse tipo de deficiência:

“Técnicas da M. oral e método P.E.I”. SRB - Fonoaudióloga

“Equoterapia, Bobath, kabat, Hidroterapia e Natação”. HADS - Fisioterapeuta

“Brinquedos cantados e natação”. M S M - Educador Físico

“Técnicas: musicoterapia perceptiva, recreação musical terapêutica, musicoterapia ativa, musicalização, Métodos Verdou Pailher DIM Yam” LRS - Musicoterapeuta

“A técnica da equoterapia é um método terapêutico e educacional que utiliza o cavalo dentro de uma abordagem interdisciplinar, nas áreas saúde, educação” CVLV - Psicóloga

"Essas duas técnicas estimular muito o funcionamento físico e motor:

- Natação Adaptada influência na prática da aptidão cardiorrespiratória dos portadores de Síndrome de Down; 
- Musculação para um aluno com síndrome de down promove uma melhora de condicionamento físico e que possibilita um trabalho de hipertrofia e resistência muscular localizada através de exercícios resistidos”. .AOS Terapeuta Ocupacional

“A Educação física e uma técnica hoje que auxiliar os portadores de Síndrome de Down a se desenvolverem, criando para eles uma oportunidade de lazer, prazer e principalmente de bem estar físico e social”. TJAA - Assistente Social

\section{Questão 9. Quanto tempo de trabalho você considera importante no desenvolver para o portador de Síndrome de Down?}

Os profissionais objetivam que o portador de Síndrome de Down consiga sua independência, tanto no ponto de vista motor (andar, pular, correr, brincar, jogar, subir e descer escadas) como no social que ele possa ter um convívio com o mundo externo, participando de grupos sociais e da mesma idade.

“Não se pode dar um tempo exato, pois não é uma doença passageira, e sim genética e eterna, então pode se levar de dias a anos”. HADS - Fisioterapeuta

“O atendimento de reabilitação, principalmente de terapia Ocupacional é de longo prazo, até seria interessante a família continuar o tratamento durante todas as fazes da vida desde a estimulação precoce até a vida adulta”. AOS - Terapeuta Ocupacional

“O Down submetido a tratamentos desde o nascimento têm melhoras em seu desempenho, mas ainda não se conhece sua efetiva contribuição na vida adulta por isso não se pode determina quanto tempo de trabalha, pois não é uma doença que passar”. CVLV - Psicóloga

“O tratamento que atualmente se faz colaborar para acelerar e melhorar as condições motoras e intelectuais do portador da Síndrome de Down, mas não tem como dar um tempo certo para o tratamento”. MSM - Educador Físico

"Sabemos atualmente que a síndrome se trata de uma alteração genética e que os portadores de Síndrome Down embora apresentem algumas dificuldades podem ter uma vida normal, mas com o acompanhamento de profissionais e familiares proporcionando uma vida adulta melhor. TJAA - Assistente Social

“O portador de Síndrome Down se desenvolve lentamente, sendo muito mais 
dependente que os outros em seu desenvolvimento, mas passará pelos mesmos caminhos, semelhantes aos das outras pessoas por isso não se pode definir quando tempo par desenvolver todos os seus estímulos”. SRB - Fonoaudióloga

“O dia-a-dia do portador ainda é bem mais lento que de uma criança com desenvolvimento normal, as diversas fases e etapas do seu desenvolvimento. são muito importantes. Apesar de o desenvolvimento lento ser comum em todas as crianças, existe diferenças marcantes entre os Down cada uma terá suas graças, seu jeito de ser, de brincar, de se comunicar e também o seu tempo de aprendizado, ficando a nosso encargo”. LRS Musicoterapeuta

\section{Questão 10. Para você qual a importância da Dança com o portador Síndrome de Down?}

A dança é uma arte que está sempre em movimento e em harmonia com a vida sobre tudo superando o preconceito de que o deficiente não pode e não deve se mover.

“A Dança é tão importante por que é outra atividade aliada a música. Todas as crianças são sensíveis e logo desenvolvem significativamente seus movimentos, coordenações, lateralidade, refletindo na escola e na sua independência”. LRS - Musicoterapeuta

“A dança e essencial, pois estimula o ritmo, o equilíbrio do tônus, lateralidade, raciocínio, memória, aspectos necessários para o Down”. SRB - Fonoaudióloga

"Melhora da coordenação motora ampla, sociabilização, aprimoramento do ritmo, expressão corporal, equilíbrio dinâmico, aumento da auto-estima, melhoria no condicionamento físico e na capacidade cardiorrespiratória”. MSM - Educador Físico

“A Dança nos busca de prazeres e a música, acompanhada por uma extroversão corporal, traduz além de prazer uma grande organização neurológica com controle do equilíbrio e organização de simetria e assimetrias harmônicas e projetadas na nossa mente como elementos que dependem de memória e habilidade favorecerá a qualquer indivíduo, principalmente aquelas que apresentam algum modelo de comprometimento”. AOS - Terapeuta Ocupacional

“A dança estimula as habilidades motoras básicas andar, saltitar em diferentes direções, bem como, girar. Além disso, também trabalha a mente com parte da coreografia, movimentos seqüenciais com os membros superiores e inferiores”. TJAA - Assistente Social 
“As vantagens da dança para cérebro são a sensação de bem estar, melhora a autoestima, redução dos sintomas depressivos e ansiosos e melhora o controle do apetite". HADS Fisioterapeuta.

“A dança melhora capacidade pulmonar fortalece a massa muscular, e aumenta a flexibilidade, pois, a atividade estimula o desenvolvimento das fibras musculares que compõem os diversos músculos do corpo”. CVLV - Psicóloga 


\section{DISCUSSÃO}

Muito tem se falado sobre a Síndrome de Down, mas um ponto se destaca: suas dificuldades cognitivas. Quais as áreas mais afetadas? Como potencializá-las? Essas são perguntas que perturbam profissionais e a sociedade. Os dados descritos acima apontam para a crescente necessidade de se buscar conhecimentos sobre a Síndrome de Down, em todos os seus aspectos, biológicos, sociais e culturais, dessa forma, evidencia-se a necessidade de oferecer acesso a informações atualizadas, que possam esclarecer pais e profissionais de diferentes áreas da saúde e educação

Todos os profissionais entrevistados sabem definir e caracterizar a Síndrome de Down como sendo a presença de um cromossomo 21 extra total ou parcialmente, causando um distúrbio genético ou uma cromossomopatia, doença cujo quadro clínico global e explicado por um desequilíbrio na constituição cromossômica, a presença de um cromossomo 21 extra que pode ocorrer com qualquer pessoa independente de raça da cor ou idade onde se caracteriza por uma atraso mental; hipotonia generalizada em diferentes graus.

Em qualquer um dos casos, nada pode ser feito para impedi-la, mas é possível preveni-la por meio de aconselhamento genético e exames como volocorial, feito após nove semanas de gravidez, com amostras de células do ponto no qual se desenvolverá a placenta, e o amniocentese, feito com o líquido que preenche a placenta, realizado entre a $16^{\mathrm{a}}$ a $18^{\mathrm{a}}$ semana de gestação. (ORNELAS; SOUZA, 2001, p. 10)

Os diagnósticos não são ainda utilizados rotineiramente pelos profissionais da APAEMA, mas todos os entrevistados indicaram passos semelhantes para o diagnóstico na suspeita de Síndrome de Down. O principal é o do Neuropediatra após o da Fonoaudióloga, sem contar com avaliação da face do paciente. As características descritas por esses profissionais foram: hipotonia muscular, reflexo de moro, hiperflexibilidade articula, fendas palpebrais, inclinadas para cima, orelhas pequenas, instabilidade atlânto-axial e pés e mãos pequenos.

Partindo das falas relatadas na entrevista dos profissionais constitui-se a importância de um conjunto de técnicas que devem ser estimuladas e aprendidas também pelos pais, familiares e a comunidade para que possam dar continuidade ao trabalho destes profissionais em casa. 
Sobre o comprometimento do Down, os entrevistados discorreram muito do intelectual, atraso na fala e na capacidade de comunicação pode ir desde uma dificuldade de aprendizagem a um retardo grave, onde cada indivíduo pode apresentar muita desigualdade entre suas habilidades cognitivas, a leve e moderado, os quais desenvolvem linguagem, aprendem a se comunicar, se expressam melhor podendo ter uma vida social tranqüila. Outro comprometimento muito falado na entrevista e que chamou atenção é o seu processo particular de se relacionar, próprio fruto de suas condições sócio-cultural, o que leva a crer na necessidade de uma boa inclusão social.

Sobre os tipos de comprometimentos que podem ser considerados recuperáveis, é normal e necessário que se ofereça ao Portador de Síndrome de Down um tratamento, que por meio de estímulos, possa ser iniciado logo após o diagnóstico formado por equipe que integre educador físico, fisioterapeuta, terapeuta ocupacional, fonoaudiólogo e psicólogo, assistente Social e musicoterapeuta. Estes profissionais irão estimular o portador para que tenha um melhor desenvolvimento cognitivo e motor. O Diagnóstico precoce, que não foi comentado pelos entrevistados, possibilita a criança com Síndrome de Down seja inserida mais cedo em um programa multiprofissional, o que vai desenvolver a sua saúde e qualidade de vida.

Foi observado que cada um dos profissionais entrevistados tem um papel especifico frente ao portador de Síndrome de Down e que por ser uma herança genética cabe a sociedade, governo, a escola a família apoiar, e buscar profissionais que estejam aptos para trabalhar com portadores de Síndrome de Down que conheçam muito bem as características físicas desta síndrome para melhor executar o seu trabalho adequando-o para o tratamento mais eficaz e uma melhoria na qualidade de vida do portador.

Embora nenhum entrevistado tenha indicado a dança como técnica para se trabalhar com o portador de Síndrome de Down, quando questionados sobre a importância da dança na vida destas pessoas, todos a consideraram uma influência importante no desenvolvimento de habilidades e competências desse distúrbio.

Para Nunes apud Calazans; Castilho; Gomes (2003, p. 37): “dançar é aprofundar o sentimento e o conhecimento da vida do corpo retratado por experiências sensoriais, imagéticas, emotivas, impregnadas do saber dos sabores”.

Tendo em vista a conclusão compreensão e a buscar para interpretação dos entrevistados da importância da dança para os portadores de Síndrome de Down verificou que se relaciona com as idéias apontadas nesse trabalho que afirmam que a dança é uma arte que está 
sempre em movimento e em harmonia com a vida sobre tudo superando o preconceito de que o deficiente não pode e não deve se mover é tão importante por que é uma atividade aliada à música. Todas as crianças são sensíveis e logo desenvolvem, significativamente, seus movimentos, coordenações, lateralidade, refletindo na escola e na sua independência.

Os profissionais entrevistados mostram a importância da dedicação dos que vão atuar com eles, principalmente, a família que iram alcançar os objetivos deste trabalho refletindo sobre a importância da dança no processo de desenvolvimento dos portadores de (SD).

“A dança deve ser utilizada para auxiliar a aquisição e manutenção da saúde, aptidão social, mental, psíquica e física” (SASSARI apud CHIARION, 2008), essa atividade estimula o portador de Síndrome de Down e proporciona uma melhor qualidade de vida. A inclusão de pessoas portadoras de necessidades especiais na sociedade é tão importante, pois proporciona uma independência em algumas situações, como o primeiro emprego, a primeira faculdade. O desenvolver da vida, vem do resultado de um bom apoio e muito carinho.

É muito importante estimular, motivar e desenvolver parcerias nos setores privados e públicos como:escolas, hospitais, entidades governamentais e não governamentais para ações sociais e, jurídicas e de saúde com investimento na melhoria da capacitação do seu corpo docente e colaboradores. A criação de departamentos específicos nas escolas e hospitais para desenvolver projetos sociais sustentável contemplando-as, estimulando a sociedade a desenvolver projetos de inclusão dos em parceria de empresas amigas dos projetos de portadores, não deixando de incentiva essas empresas aumentando os incentivos fiscais.

Como estimular o crescimento através de investimento e de incentivo por parte do governo que é uma peça fundamental para criação de departamentos específicos para pratica tal atividade com profissionais capacitados, que saibam como lidar com determinadas situações. Assim como projetos sociais e sustentáveis para os portadores é seus familiares.

A inclusão social dos portadores de síndrome de Down mostra que essas crianças podem levar uma vida igual à de outras. Avanços existem, mas ainda falta muito. Quanto mais a sociedade tiver informações, a tendência é o preconceito diminuir, pois muitos ainda não estão preparados para receber crianças com síndrome de Down. Para isso é importante a participação em atividades que façam o Portador de Síndrome Down se relacionar ao máximo com outras pessoas. É o caminho para sua integração cada vez mais à sociedade e às instituições escolas, sistemas de saúde, vida em comunidade e força de trabalho. 


\section{CONCLUSÃO}

O desenvolvimento de uma concepção epistemológica e dinâmica que denota preocupação com a questão social e vislumbre uma participação ativa desses indivíduos na sociedade quanto à minimização de suas seqüelas.

Neste ínterim, percebe-se claramente que a Síndrome de Down enfrenta um grande desafio não só na sociedade, mas também na sua própria aceitação diante de suas limitações. A qual fundamenta nossa pesquisa iniciando uma discussão no âmbito social.

Sabe-se que numa pesquisa deste porte não é possível o “esgotamento” do tema e, em hipótese alguma teve-se a pretensão de fechá-lo, mas, ao contrário, seu formato é de proposição, abertura, feixe de possibilidades. Encontrando a satisfação de um público alvo.

Todavia, apesar das dificuldades encontradas em termos de produções teóricas de suporte, ao elencar as propostas que constam no final deste Trabalho de Conclusão de Curso, objetiva-se não apenas apontá-las no formato teórico exigido, mas vislumbrar a real possibilidade de torná-las públicas e deixarem à mera especulação de “idéias”, formando uma unidade teóricoprática, contribuindo efetivamente com a transformação da sociedade às quais serão contempladas com a nossa ação.

Através dessa grande discussão pode-se determinar uma mudança no paradigma da “deficiência” para a construção de uma visão social mais abrangente que possibilite a formulação de estratégias que contemplem uma intervenção mais direta no tocante ao social.

São caminhos agora apresentados e que neles reside a certeza de que podem levar à profundas modificações na relação entre o deficiente e a sociedade, contribuindo com o bem estar coletivo. Resta, então, percorrer estes caminhos. 


\section{REFERÊNCIAS}

ALVES, Elioenai D. O agir comunicativo e as propostas curriculares. Pelotas: Editora Universitária IUFPEL, 2000.

AMARAL, Fabiana Pereira do. A representação da dança na história judaico-cristã. Disponível em: http://www.ciencialit.letras.ufrj.br/garrafa13/v2/fabianapereira.html Acesso em: 8 mar. 2008.

BEE, Helen. A criança em desenvolvimento. 9. ed. Porto Alegre: Artmed, 2003.

BÍBLIA Católica Online. Disponível em: http://www.bibliacatolica.com.br/ Acesso em: 20 mar. 2008.

BURNS, N.; GROVE, S. Understanding Nursing Researchs. Philaldelphia, PA: W.B. Saunders Co. 1995.

BRANT, Ana Clara, Os Benefícios da dança. Jornal Pampulha, 11-17/06/2005, pág. A3. Disponível em: http://www.bhservico.com.br/danca.htm. Acesso em: 20 mar. 2008.

BREGOLATO, Roseli Aparecida. Cultura Corporal da Dança. São Paulo: Ícone, 2000. v.1.

CAMINADA, Eliana. Entendendo a dança 6: Grécia, berço da civilização ocidental. Disponível em: www.portaldafamilia.org/artigos/artigo374.shtml Acesso em: 20 abr. 2008.

CASARIN, Sonia (coord.) O que é cariótipo. São Paulo: Centro de Informação e pesquisa do Síndrome de Down, [sd]. Disponível em: www.projetodown.org.br. Acesso em 10 mar. 2008.

CHIARION, Bruna Maria Macedo. Dança e desenvolvimento de idosos institucionalizados. Disponível em: http://www.unimep.br/phpg/mostraacademica/anais/5mostra/2/144.pdf Acesso em: 20 mar. 2008

FAHLBUSCH, Hannelore. Dança Moderna - Contemporânea. Rio de Janeiro: Sprint, 1990.

FARO, Antonio José. Pequena História da Dança. Rio de Janeiro: Jorge Zahar Ed., 1986. p. 1333.

FÁTIMA, Conceição Viana de. DANÇA: linguagem do transcendente. 2001. Dissertação (Mestrado em Ciências da Religião). Departamento de Filosofia e Teologia, Universidade Católica de Goiás, Goiânia, 2001. 
FIGUEIREDO, Valéria M.C. de; TAVARES, Maria da Consolação G.C.F.; VENÂNCIO, Silvana. Olhar para o corpo que dança: Um sentido para a pessoa portadora de deficiência visual. Revista Movimento, Ano 5, n. 11, 1999. Disponível em: http://www.seer.ufrgs.br/index.php /Movimento/issue/view/176. Acesso em:10 mar. 2008

FIÓRIO, Lucidélia Carpanedo. Alguns Aspectos Relevantes sobre o estudo do Movimento para o Desenvolvimento Técnico, Expressivo e Criativo do Dançarino. Disponível em: http://www.conexaodanca.art.br/imagens/textos/artigos/Alguns\%20Aspectos\%20Relevantes\%20 sobre\%20o\%20estudo\%20do\%20Movimento.htm Acesso em: 20 mar. 2008

GARAUDY, Roger. Dançar a vida. Trad. de Glória Mariani e Antonio Guimarães Filho. 3. ed. Rio de Janeiro: Nova Fronteira, 1980.

GESTAL, Simone Borges Pontes; MANSOLDO, Antonio Carlos. A importância da atividade física na melhoria da qualidade de vida dos portadores da síndrome de down. Revista Digital, Buenos Aires, Ano 13, n. 119, Abr. 2008. Disponível em: http://www.efdeportes.com/ efd119/atividade-fisica-dos-portadores-da-sindrome-de-down.htm Acesso em: 09 mar. 2008.

MAGALHÃES, Marta Claus. A dança e sua característica sagrada. Rev. Eletrônica do grupo PET, Ano 1, n. 1, jan./dez. 2005. Disponível em: http://www.miniweb.com.br/Artes/artigos /danca.pdf Acesso em: 20 mar. 2008.

MESQUITA, Kamila; ZIMMERMANN, Elizabeth B. Dança: Estímulo ao Desenvolvimento de Crianças Portadoras de Deficiência Mental. Revista Digital, ano 4, n. 5, abr. 2006. Disponível em: http://www.revista.art.br/site-numero-05/trabalhos/01.htm. Acesso em: 10 mar. 2008.

MINAYO, Maria C. S. O desafio do conhecimento: pesquisa qualitativa em saúde. Rio de Janeiro: Abrasco, 2000.

MOREIRA, Lília M. A.; EL-HANI, Charbel N.; GUSMÃO, Fábio A. F. A síndrome de Down e sua patogênese: considerações sobre o determinismo genético. Rev. Bras. Psiquiatr., v. 22, n. 2 p.96-99, Jun. 2000. Disponível em: http://www.scielo.br/pdf/rbp/v22n2/a11v22n2.pdf. Acesso em: 2 mar. 2008.

NANNI, Dionísia. Dança educação: Pré-escola à universidade. Rio de Janeiro: [s n], 1995. p. 75-85.

OLIVEIRA, Sávio Assis de. Reinventando o esporte: possibilidades da prática pedagógica. 2 ed. Campinas: Autores Associados, 2005. 
ORNELAS, Márcia Abrantes; SOUZA, Celso. A contribuição do profissional de educação física na estimulação essencial em crianças com Síndrome de Down. Revista da Educação Física. Maringá, v. 12, n. 1, 2001 Disponível em: http://www.def.uem.br/revistadef/admin/artigos /e449568a9e21dbb17531c77295ae9d8b.pdf. Acesso em: 10 mar. 2008.

PAVLOVIC, B. Ginástica aeróbica. Tradução de Denise Vaudois Pereira da Silva e Dimas Pereira da Silva. Rio de Janeiro: Sprint, 1987.

PETO, Ana Carla. Terapia através da dança com laringectomizados: relato de experiência. Rev. Latino-Am. Enfermagem. v.8, n.6, dez 2000.

SÉRGIO, Manuel. Motricidade Humana e Saúde. Revista da Educação Física. Maringá, v. 12, n. 2, 2001. Disponível em: http://www.def.uem.br/revista/revista_12a/art_14_12a.htm. Acesso em: 20 fev. 2008.

SILVA, Diorges Ricardo da; FERREIRA, Juliana Saraiva. Intervenções na Educação Física em crianças com Síndrome de Down. Revista da Educação Física. Maringá, v. 12, n. 1, 2001. Disponível em: http://www.def.uem.br/revista/revista_12/art_08_12.htm. Acesso em: 09 mar. 2008.

SILVA, Maria de Fátima Minetto Caldeira; KLEINHANS, Andréia Cristina dos Santos. Processos cognitivos e plasticidade cerebral na síndrome de down. Rev.Bras. Educ. Esp., Marília, v.12, n.1, Jan./Abr. 2006. Disponível em: www.scielo.br/pdf/rbee/v12n1/31988.pdf Acesso em: 20 mar. 2008.

SCHWARTZMAN, José Salomão. Síndrome de Down. São Paulo: Mackenzie, 1999. 